\title{
STUDIES ON THE PERMEABILITY OF CELLS
}

\section{EDMUND NEWTON HARVEY}

\author{
From the Zoological Laboratory, Columbia University
}

THREE FIGURES

\section{CONTENTS}

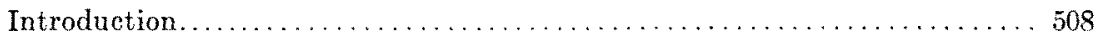

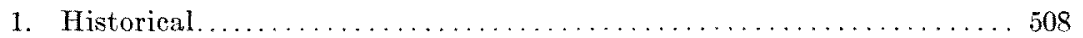

2. Theories concerning permeability $\ldots \ldots \ldots \ldots \ldots \ldots \ldots \ldots \ldots \ldots \ldots \ldots, 509$

3. Methods of testing permeability . . . . . . . . . . . . . . . . 512

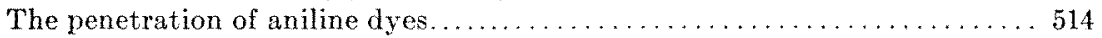

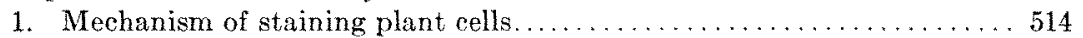

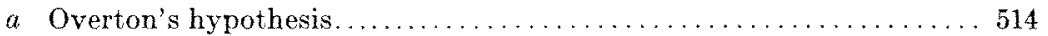

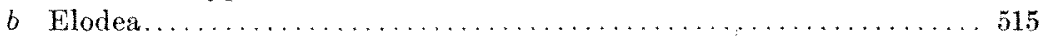

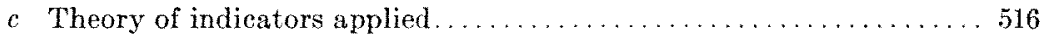

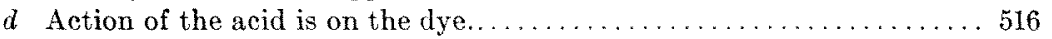

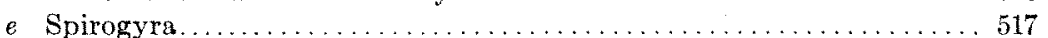

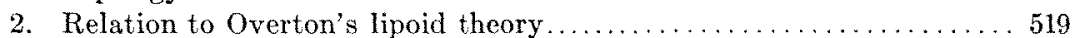

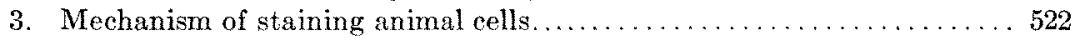

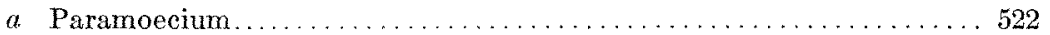

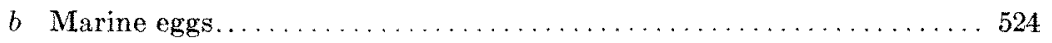

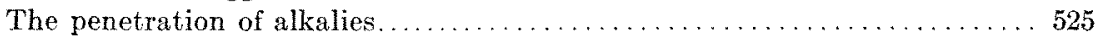

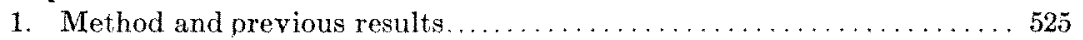

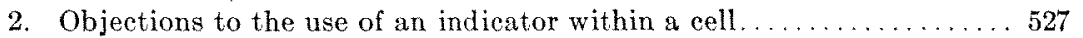

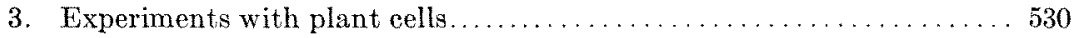

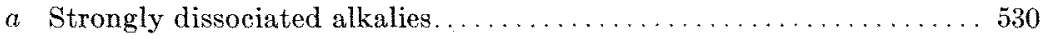

$b \quad$ Weakly dissociated alkalies. . . . . . . . . . . . . . . . . . . 532

$c$ Permeability of cells exhibiting protoplasmic rotation......... 536

$d$ The concentration of alkali which stops rotation. . . . . . . . 537

$e$ The effect of added substances on the penetration of $\mathrm{NaOH}$ and $\mathrm{KOH} 538$

4. Experiments with animal cells..................... 541

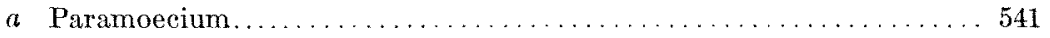

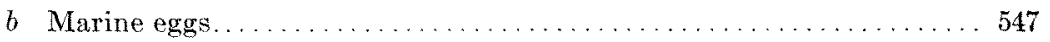

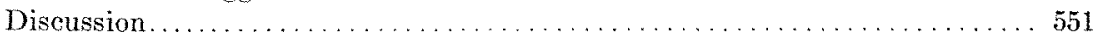

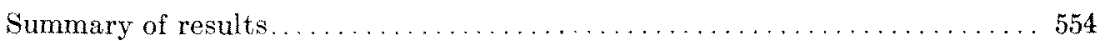

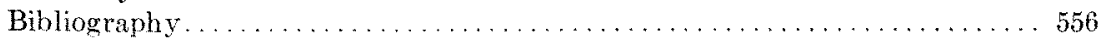




\section{INTRODUCTION}

\section{Historical}

Within the past fifty years a great deal of scientific research has been directed toward advancing our knowledge of the manner in which substances may pass into living cells and of the classes of substances which may or may not enter. Intimately connected with the question of the permeability of cells are the phenomena arising from the existence of an osmotic pressure without and within the cell, and the rigidity or turgor of plant parts directly dependent on the latter. This relation is most evident when we recall that the existence of a continual turgor of plant structures depends on the possession, by the individual cells, of a surface membrane which prevents the diffusion outward of most of the substances dissolved in their sap vacuoles.

Questions concerning osmotic pressure must therefore always go hand in hand with questions concerning the permeability of the membrane whose presence is one condition for the existence of that pressure. Historically the two subjects have developed simultaneously.

It is hardly within the scope of this paper to give a detailed account of the history of this complicated subject, so numerous are the papers dealing with its different phases. The fundamental facts were outlined by three observers during the latter half of the last century. Their influence has been so great that I shall mention briefly the contribution of each.

Nägeli ('55) first investigated the osmotic properties of the cell and made clear the cause of turgor and of plasmolysis. The word plasmolysis was introduced later by DeVries. It is to Pfeffer (77, '86, '90) and DeVries, ('71, '77, '84, '85) however, that we owe our present conception of the important rôle played by diffusion and osmotic pressure. Both of these authors investigated the magnitude of the pressures existing in plant cells and the properties of the cell membranes. Pfeffer has especially emphasized the conditions under which accumulation of substances takes place; DeVries the importance of the vacuolar 
membrane, designated by him the tonoplast. The generalizations made by these three botanists, in which the discovery of semipermeable precipitation membranes by M. Traube ('67) has played a most important part, have been extended and confirmed by a host of recent experimenters, Overton, Hoeber, Nathanson, Ruhland, Hamburger, R. Lillie, Koeppe, Gryns, Hedin, Asher, J. Loeb, and many others. Although most studies on permeability have been carried out on plant cells, the same essential relations are exhibited by animal cells.

\section{Theories concerning permeability}

The more recent studies, especially those of Overton ('95, '97, '99, '00), have been concerned with the classes of substances which may or may not pass the plasma membrane. This at once raises two important questions.

1. How does a substance enter?

2. What is the nature of the cell surface or plasma membrane?

In answer to each of these questions several theories have been advanced. Let us consider first the nature of the plasma membrane.

Quincke ('88), in order to account for the power of movement of amoeboid cells as well as certain peculiar osmotic properties, assumed that a thin film of oil was present at the surface. Overton has explained the very rapid entrance of ether and fatsoluble substances by assuming that the plasma membrane is composed largely of lipoids like lecithin. This view was later modified to explain the entrance of substances insoluble in lipoids by regarding the cell surface as a mosaic of proteid plus cholesterin (Nathanson, '04, a) or proteid plus lecithin. On the other hand Pfeffer has always insisted that the membrane is chiefly proteid, while Robertson ('08) considers it a form of modified protein comparable to that which remains about droplets of chloroform shaken up with protein solutions and then washed repeatedly in water. 
Three general theories, based on Van't Hoff's view of the driving power in osmosis, have been advanced to account for the passage of substances through membranes:- the filter theory, the solution theory, and the chemical combination theory. The filter theory regards a membrane as a molecular sieve. Whether it is permeable to a given substance will depend on the relative sizes of the molecules of the substance and the interstices of the membrane. A study of artificial precipitation membranes has afforded considerable evidence against such a simple explanation. According to the second theory a substance must dissolve in the membrane in order to pass through, and according to the last theory the substance must combine with the membrane before it may pass.

J. Traube, ('04, '08, '09, '10) on the other hand, regards the driving force in osmosis, as an 'Oberflächendruck,' later called 'Haftdruck,' measured by the tendency of the substance to increase or decrease the surface tension of the solvent. The membrane separating two phases is not the important thing but the difference in surface tensions, the phase of lowest surface tension tending to pass through the membrane into that of greater surface tension. Traube admits that the Haftdruck of the membrane may also be a determining factor ('10, p. 533).

At present there are two general views as to the classes of substances which may diffuse into cells. These are based largely on conceptions regarding the nature of the cell membrane and the physical or chemical process by which a substance may pass it. The results obtained by different methods of investigation and their interpretation have been in many cases conflicting.

Inasmuch as my studies on the permeability of cells show in the clearest manner the existence of two distinct classes of alkalies with respect to their ability to enter, a brief statement of the opposed views may not be out of place.

Overton and Hoeber classify substances into lipoid-soluble and lipoid-insoluble. The former are found to enter cells very rapidly, the latter not at all when tested by the plasmolytic method (p. 512). Yet the lipoid-insoluble substances are just those which we know by analysis and microchemical tests to 
occur in cells (inorganic salts, sugars, etc.). Further, the entrance of $\mathrm{KNO}_{3}$ can be demonstrated by the diphenylamine reaction, while the cell remains plasmolysed. Consequently Overton and Hoeber assumed that cells have a physical and a physiological permeability. The lipoid soluble substances enter in a purely physical manner, by simple diffusion, involving solution in the lipoids of which the plasma membrane is assumed to be composed. The lipoid-insoluble substances enter in some other way, but not by diffusion. As evidence of this Overton calls attention to the fact that the neutral salts, sugars, etc., are just the substances which are known to pass into cells or through cells from regions of lower to regions of higher concentration without chemical change. Some other factor than diffusion must be involved.' Hoeber ('09) now admits that the lipoid theory does not hold for dyes and that it must undergo more or less remodelling (p. 78).

On the other hand, Overton's opponents draw no distinction between lipoid-soluble and lipoid-insoluble substances, but regard the entrance of any solute as a process of simple diffusion, (without considering how the substance passes the membrane), the only difference lying in the relative rates of diffusion.

The presence of salts in cells in different proportions from the medium is explained as due to combination with proteids in the cell. Indeed, Moore and Roaf ('07) have gone so far as to deny any importance to the existence of a surface membrane in regulating the entrance of salts into red blood corpuscles, but regard the difference in salt content between cell and medium as entirely due to formation of salt proteid compounds.

A great deal of confusion has arisen from the fact that a cell may change in permeability from time to time. Differences are

\footnotetext{
I It would seem that we must draw the distinction between the accumulation of salts in solution in vacuoles and the existence of salts (as determined by chemical analysis) in the protoplasm of cells without such structures. The former is a phenomenon comparable to the passage of $\mathrm{NaCl}$ through loops of intestine from dilute to more concentrated solution. Two bounding surfaces are involved. The latter is possibly explainable by the formation of ion-proteid compounds within the cell as developed by Moore and Roaf (Biochemical Journal, Vol. 3 , p. 55, 1907) to account for the high $K$ content of the red blood corpuscle.
} 
to be noted especially between rest and activity, due to stimulation. A further source of error results from the fact that the very substance whose penetration we are studying may change the permeability of the cell in the concentrations used. This naturally leads to a brief consideration of the methods of testing permeability used by various authors. They may be conveniently classified as follows:

\section{Methods of testing permeability}

1. Plasmolytic or osmometric (depending on changes in volume and turgor of the cell).

a. Direct observation of plasmolysis (DeVries, Overton).

$b$. Indirect, by noting cessation of movement in motile bacteria (Wladimiroff, Zeit. f. physik. Chem. 7 p. 527, 1891).

c. Indirect, by weighing (Overton, Pfüger's Archiv. 92, p. 115, 1902, Loeb, Pflüger's Archiv. 69, p. 1, 1897 and E. Cooke, Journal of Physiology, 23, p. 137, 1898).

d. Indirect, by noting liberation of haemoglobin in isotonic permeating solutions (Gryns, Pflüger's Archiv. 63, p. 86, 1896).

e. Indirect, by determining change in volume of centrifuged corpuscles (Koeppe, Gryns, Hedin).

$f$. Indirect, by determining the concentration in sea water and the concentration, pure, capable of causing artificial parthenogenesis (Loeb. Univ. of Calif. Pub. 3, p. 81, 1908)

2. Observational a. Directly, as the entrance of dyes (Pfeffer, Overton, Hoeber, Ruhland).

$b$. Introduction of an indicator (as neutral red) and subsequent change.

c. By some change produced in a substance (as tannin) already present in the cell (Overton, Zeit. Physik. Chem. 22, p. 189, 1897).

d. By microchemical tests (as the determination of $\mathrm{KNO}_{3}$ by diphenylamin; Molish). 
3. Analytical (chemical or otherwise) a. By analysis of cells themselves.

b. By analysis of medium (chemically, or by determining freezing point or electrical conductivity) after diffusion into the cell has taken place.

c. By analysis of the medium after diffusion from the cell has taken place.

4. Conductivity [of blood corpuscles (Stewart, Tangl and Burgarszky, and Roth) or of eggs (McClendon)].

5. Alteration of function (on the assumption that to affect a cell the substance must enter).

a. Test by toxicity.

b. Test by narcosis (Overton).

c. Test by change in manner of response to stimuli (Loeb, Dynamics of Living Matter, p. 842, New York, 1906).

d. Test of effectiveness in causing artificial parthenogenesis (Loeb, J., Chemische Konstitution und physiologische Wirksamkeit von Sauren. Biochemische Zeitschrift, 15, p. 254, 1909).

No one of the above methods can be claimed as universally better than any of the others. Recent researches have exposed sources of error in the application of the plasmolytic method (Osterhaut, '08). Mass analyses of cells give us no hint as to the location of the substance in the cell or the state in which it is present, in solution or in combination.

The evidence (pp. 543-546) in the case of the inorganic hydroxides shows that these alkalies may produce functional changes and death of Paramoecium without entering in sufficient quantity to affect granules stained in neutral red within the cell, and its effect must be on the membrane. Hoeber regards the surface of the cell as the point of attack of the strongly dissociated substances in general. Only after the cell surface has been fundamentally modified does the reagent pass in.

Whenever applicable the observational methods are most useful in studying problems in permeability, for they not only answer the general question concerning penetration of the substance in question, but also enable us to locate the reagent in the cell and 
to determine changes in function associated with the entrance of a given quantity.

Most of the present experiments were performed in the Zoölogical Laboratory of Columbia University. The study of marine eggs was made possible by a visit to the Tortugas Laboratory of the Carnegie Institution and the Marine Biological Laboratory at Woods Hole. I wish to express my indebtedness to Dr. Mayer for the many special opportunities for research offered me at the former station and to Dr. Morgan for permission to use a Columbia table at Woods Hole as well as for many helpful suggestions.

\section{THE PENETRATION OF ANILINE DYES}

\section{Mechanism of staining plant cells}

In studying permeability for alkalies, to be discussed below, penetration was indicated by the change in color of neutral red in which the cells had been stained. In order to determine under what conditions neutral red exists in the cell and the nature of the dye compounds which the alkali must decompose on entering, I have conducted a few experiments on certain dyes with the above points in mind. The most interesting fact obtained is that basic dyes as a rule cannot enter cells in the presence of a trace of acid in the medium whereas certain acid dyes do not enter cells in neutral or weakly alkaline solution but readily stain and kill the cell in weakly acid solution. We should naturally suppose the explanation of the above results to be in the effect of the acid or alkali on the dissociation of the dye molecules.

$a$. Overton's hypothesis:-Overton had at one time supposed that only the free dye base of basic dyes might enter cells. Since basic dyes are combination of weak bases with strong acids we should expect them to be hydrolytically dissociated in water, thus:

$$
\mathrm{RCl}+\mathrm{H}_{2} \mathrm{O}=\mathrm{ROH}+\mathrm{HCl}
$$

Only the $\mathrm{ROH}$ and not the $\mathrm{RCl}$ might enter. Overton ('00) later abandoned this idea since he was unable to show that the dye acetates entered the cell more readily than the dye chlorides. 
The combination of a weak base and a weak acid undergoes a greater hydrolytic splitting, more of the free dye base is produced, and the cell should stain more rapidly in the acetate. But such was not found to be the case.

The addition of a slight amount of acid will prevent the hydrolytic dissociation and this test must be a surer one than Overton's. I have consequently come to the conclusion that Overton's first hypothesis is the correct one. The detailed evidence for this is given below. The dyes used are mostly the same that Overton experimented with belonging to the triphenylmethane and chinonimid groups.

b. Elodea:-Pfeffer ('86) first studied the absorption of aniline stains and gave us a clear account of the mechanism of accumulation. The dyes collect as granular colored tannin precipitates in Spirogyra. The case of Elodea is different. Neutral red is not typically precipitated, but collects in solution of a red color. ${ }^{2}$ It likewise collects as a red solution in the vacuole from alkaline tap water of a pale yellow color. This suggested that the sap vacuole is slightly acid and in the acid condition neutral red cannot pass out. Consequently it is slowly accumulated. (Harvey '10). I was thus led to try staining in weakly acid solution. While it is true that neutral red does not enter from the $\mathrm{HCl}$ or $\mathrm{CH}_{3} \mathrm{COOH}$ acid condition, the acid present in Elodea is probably a very complex organic one. I have been unable to detect any red coloration by crushing the leaves on blue litmus paper.

The following experiment shows that the dye will not pass into the cell in the acid condition. Elodea leaves were placed in each of the following solutions:
A. 50 ec. tap water +1 drop 0.1 per cent neutral red.
B. 50 ec. $0.001 \mathrm{n}$ HCL +1 drop 0.1 per cent neutral red.
C. 50 ce. $0.001 \mathrm{n} \mathrm{NaOH}+1$ drop 0.1 per cent neutral red.

After six hours the leaf cells in A and $\mathrm{C}$ were found to have accumulated large quantities of the dye while the cells of $\mathrm{B}$ contain no dye at all. Leaves in B are not injured for protoplasmic

${ }^{2}$ In some cells red globules may be seen; In others red needle erystals. In alkaline condition neutral red is yellow; in neutral and acid condition, red. 
rotation goes on and when placed in A they were able to collect the dyestuff from the surrounding solution. The stain may be 'adsorbed' by the cellulose cell walls from acid solutions just as it is adsorbed by glass only when in the acid condition. But this phenomenon has nothing to do with the question of the permeability of the cells for the dye, although on casual observation the appearance of dye accumulation may be given. Elodea cells fail also to stain in $\frac{N}{200}$ acetic acid, yet accumulate the dye if transferred to a neutral solution. ${ }^{3}$

c. Theory of indicators applied: Indicators as neutral red or litmus are very weak bases or acids. According to Ostwald, the color change is due to the transformation of the acid or base into a salt which is very highly ionized. The ions give the color to the solution and their color is different from that of the undissociated molecule of the free color base or acid, only slightly ionized in solution. Neutral red has the following structure:

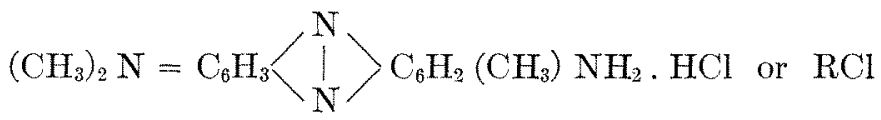

A small amount of acid converts all of the neutral red into dissociated $\mathrm{R}+$ and $\mathrm{Cl}$-. A small amount of alkali forms $\mathrm{ROH}$, undissociated, and it is the undissociated color base which may enter cells. In the neutral condition a small proportion of free base $\mathrm{ROH}$ is present, due to hydrolytic dissociation. Consequently cells may be stained in neutral solution.

d. Action of the acid is on the dye: That the effect of the acid is on the dye and not on the plasma membrane of the cells, decreasing its permeability, is made probable by the following facts.

1. Certain acid dyes (eosin) enter only in the presence of dilute acid and fail to enter in alkaline solution.

2. The presence of dilute $\mathrm{HCl}$ does not prevent the toxic effect of heavy metal salts like $\mathrm{CuCl}_{2}$.

\footnotetext{
3 The observations refer only to the normal rotating cells and not to certain large cells filled with a mass of white granular matter, which stains in acid solution.
} 
3. The relations of basic dyes are exactly comparable to those found by Overton ('97) for certain alkaloids which are weak bases, and do not enter cells in acid solution. In the acid an alkaloid salt is of course formed.

I have observed that caffein, on the contrary, enters equally well in acid, neutral, and alkaline solution. It was compared with strychnin in similar percentage concentrations:

Spirogyra cells were placed in the following solutions:
A. 0.01 per cent strychnin sulphate in $\frac{\mathrm{N}}{750} \mathrm{NaOH}$ tap water.
B. 0.01 per cent strychnin sulphate in $\frac{\mathrm{r}}{\mathrm{r}} \mathrm{\textrm {J }} \mathrm{\textrm {HCl }}$ tap water.
C. 0.01 per cent strychnin sulphate in tap water.
D. 0.0125 per cent caffein in $\frac{\mathrm{N}}{50} \mathrm{NaOH}$ tap water.
E. 0.0125 per cent caffein in $\frac{x}{50} \mathrm{HCl}$ tap water.
F. 0.0125 per cent caffein in tap water.
G. $\frac{\mathrm{N}}{750} \mathrm{NaOH}$ tap water.
H. $\frac{\mathrm{N}}{7 \frac{5}{50}} \mathrm{HCl}$ tap water.

In $\mathrm{A}$ the strychnin passes into the cells and forms a granular reticulum and within twenty minutes the cells have lost their turgor and secrete a sticky substance. In C strychnin also enters but less rapidly and death results after about one hour. In B no strychnin precipitate is formed and the cells are normal after one hour.

In $\mathrm{D}, \mathrm{E}$, and $\mathrm{F}$, an equal amount of caffein precipitate is formed after 45 minutes in each case.

The cells in $\mathrm{G}$ and $\mathrm{H}$ are quite unaffected by the acid or alkali after one hour.

e. Spirogyra: Exactly the same permeability relations hold for Spirogyra, sea urchin and starfish eggs, and Paramoecium. The mechanism of accumulation is different in each case. In the study of dyes we have always to consider two points - in what condition the dye enters and by what means it is made visible within. There must always be an accumulation of some kind for otherwise the color would not be apparent in so small a layer.

I have also studied the entrance of several others dyes in the acid and alkaline condition into Spirogyra and the same general law appears to hold. The results are best given in the form of a table which does not pretend to be exhaustive, but simply to 
show that the conditions determining absorption of neutral red are equally true of other classes of dye stuffs (table 1 ).

Besides Pfeffer's original monograph, the most important comparative studies of permeability for the aniline dyes have been made by Overton, Ruhland, and Hoeber and Robertson.

Overton ('00) studied the permeability of both plant and animal cells in neutral solution for many different dyes and the solubility of the same dyes in olive oil and mixtures of lipoids. He came to the conclusion that the lipoid-soluble dyes enter living cells and the lipoid-insoluble do not. It has since been found that there are certain exceptions to Overton's conclusion.

Ruhland ('08) pointed out that there are some dyes which are lipoid soluble and fail to enter living cells, others are lipoid insoluble yet enter readily and still others which may enter, yet show no relation between rate of entrance and solubility in lipoids.

Hoeber's ('09) recent study of the same question gave a similar result to that of Ruhland with respect to certain dyes. He concludes that the facts correspond better with the 'Satz' that basic dye stuffs are intra vitam stains and acid dye stuffs are not.

Robertson ('08) has attacked Overton's original position by a study of the partition coefficient of various analine dyes in ethylacetate, ethylbenzoate, triacetin and triolein. He came to the conclusion that the solution of an acid dye in fatty substances is increased by the addition of acid, the basic by the addition of an alkali. In other words the free color acids or bases are more soluble in lipoids than their salts. Robertson also studied the stainability of fat cells, connective tisue cells, and red blood corpuscles (fixed on a slide) in acid and alkaline solution. But the $\mathrm{HCl}$ and $\mathrm{NaOH}$ used were so strong $\left(\frac{\mathrm{N}}{\mathrm{T} \sigma}\right)$ that they must have killed the cells and no conclusions as to the permeability of living cells can be drawn from his experiments.

I have observed also the stainability of the yolk platelets of the frog's egg in dilute solution of analine dyes in the acid and alkaline condition. These bodies are likewise more readily stainable by the free color acids and bases than their salts. I will discuss this matter later. 
The acid solutions contained $\frac{N}{10 \pi} \mathrm{HCl}$; the alkaline $\frac{N}{1000}$ $\mathrm{NaOH}$ in tap water; neutral solutions were of glass distilled water. The acid had no effect on the Spirogyra during the short time of the experiment, under four hours. The dyes (all prepared by Grübler and Co.) were of such concentration as to give a very light colored solution in a layer $3 \mathrm{~cm}$. thick. Many dyes cannot be satisfactorily studied because they become colorless very rapidly in alkaline solution and less rapidly in neutral solution. The letter B in the next table placed after the dye signifies that it is basic; A signifies an acid dye. In the last column is given the stainable power of the yolk platelets of the frog's egg in the same dilute dye solutions used in the study of Spirogyra. The platelets were obtained from the ovarian eggs of Rana catesbiana. They are regarded by McClendon ('10) as a lecithalbumin "composed of 6 per cent lecithin and 94 per cent batrachiolin, a nucleo-albumin containing 1.2 per cent phosphorus, 1.3 per cent of sulphur, and 15 per cent of nitrogen."

The entrance of all the basic dyes studied is indicated in Spirogyra by precipitation with tannic acid as fine colored granules, just as is neutral red. On the contrary the penetration of the acid dyes is accompanied by a combination of the dye with the cell proteids, nucleus and pyrenoids appearing colored first, then cytoplasm and chlorophyll bands. The spiral bands are often distorted, the nucleus swollen and turgor is invariably lost. This is true of all the acid dyes given in the following table and is indicated by the word stained. As mentioned above the appearance of cell staining is often given by a union of the dye with the cellulose wall but this is readily detected by high magnification. It is obvious that only the presence of colored granules in the sap vacuole or the staining of the protoplasm should be regarded as criteria of permeability.

\section{Relation to Overton's lipoid theory}

It will be seen from table 1 that it is the free color bases or acids which enter cells and not their salts and this is the sameresult which Robertson obtained in studying the solubility of dyes in 
TABLE 1

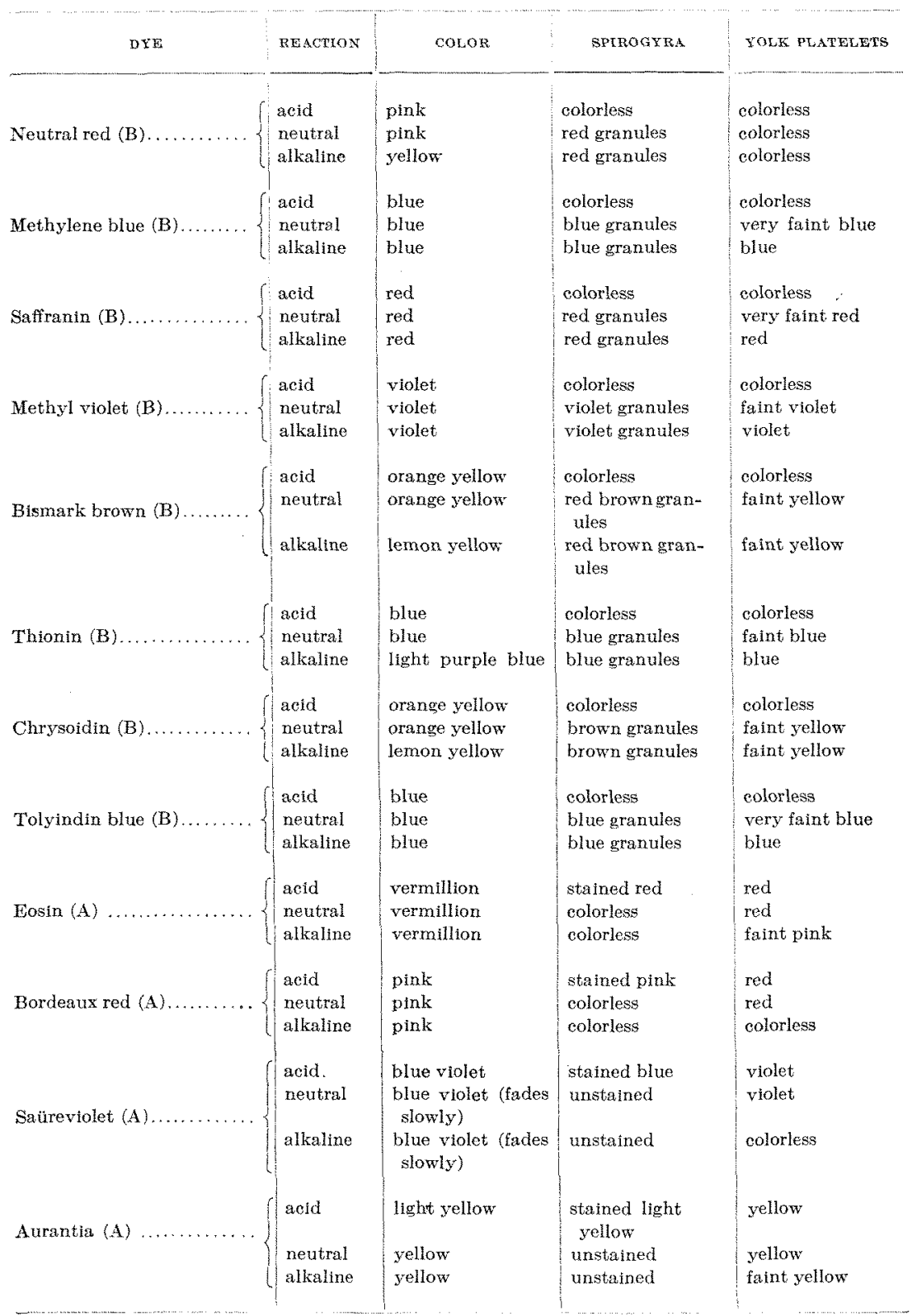


fatty substances and fat solvents. It must not be forgotten that, as Mathews ('98) showed, the basic stains yield colored precipitates with proteids only in alkaline solution, the acid only in acid solutions. The same was found to be true of the staining of coagulated proteids as egg albumen. We should expect therefore that the lecithalbumen platelets of the frog's egg would show the same staining relations that Mathews found for coagulated albumen, even from very dilute solutions. It is probable that the acid or alkali affects the lecithalbumen as well as the dye.

We might draw the conclusion from this that a dye only enters a cell when it combines with the surface membrane. ${ }^{4}$ Yet I have never noticed that the plasma membrane of any cell becomes stained in dilute solutions of basic dyes. The most conspicuous fact connected with the staining of plant cells is that the stain passes through the cell protoplasm without affecting it in the least and collects in the vacuole.

My studies on dyes have not been extensive enough to warrant generalizations as to the classes of dyestuffs for which cells are permeable nor as to the nature of the cell surface. It appears to be true - as a general rule, to which there are exceptions - that the substances (including alkaloids, alkalies, dyes, anaesthetics, etc.) more soluble in fat solvents or fatty substances than in water, penetrate cells with practically no resistance, while those compounds insoluble in ether and fats meet a marked resistance at the cell boundary as Overton has postulated. But whether we are to conclude from this that the boundary is lipoid in nature is quite another question. The evidence on this point is far from conclusive. Indeed, Traube has shown that the lipoid soluble substances, the easily permeating substances, are those having the greatest tendency to lower the surface tension of waterin air, and, according to his theory of osmosis to pass into the phase of greater surface tension (into the cell). No lipoid membrane separating the two phases is required.

\footnotetext{
${ }^{4}$ Mathews ('10) has recently concluded that the dyes penetrate by "combination with substances in the peripheral layer such as lecithin and the electro-negative proteins, soaps and possible other substances." (p. 218). He regards the taking up of basic dyes by lipoid solvents, which act as weak acids, as a chemical combination.
} 


\section{Mechanism of staining animal cells}

Animal cells show the same relations toward neutral red as do plant cells: Paramoecia were placed in the following solutions:

A. 10 ce. tap water $+0.1 \mathrm{cc} . \frac{N}{N 0} \mathrm{HCl}\left(\frac{\mathrm{N}}{\mathrm{T} 00}\right)+1$ drop $0.02 \%$ neutral red.

B. $10 \mathrm{ce}$. tap water $+0.1 \mathrm{cc}$. $\frac{\mathrm{N}}{10} \mathrm{NaOH}\left(\frac{\mathrm{N}}{1000}\right)+1$ drop $0.02 \%$ neutral red.

C. $10 \mathrm{cc}$. tap water +1 drop $0.02 \%$ neutral red.

After 30 minutes the individuals in $\mathrm{A}$ are unstained while those in $\mathrm{B}$ and $\mathrm{C}$ are very deeply stained. In one hour the Paramoecia in $A$ show a faint pink color in some of their vacuoles, and later they become noticeably stained. This is probably due to the fact that the animals are constantly forming new food vacuoles. A small amount of neutral red enters with the fluid of the vacuole. The acid passing in at the same time is neutralized and the dye may then pass the wall of the vacuole and stain certain granular bodies in the protoplasm. Paramoecia stain after some time in acid solutions not because the dye may pass the surface membrane but because it is engulfed along with the food of the organism. The food eaten may itself be stained.

If paramoecia stained in neutral red are centrifuged in an electrical centrifuge for one and one half hours it is easy to differentiate the bodies with which the dye unites. Six more or less distinct zones may be distinguished. These very soon mix again due to the constant rotation of the protoplasm. Their relative volumes are indicated in fig. 1 .

Only two substances in Paramoecium are found stained (1) the food and granules in some of the vacuoles; (2) the minute granules which often form a ring about the food vacuoles. Macro and micronucleus, trichocysts, cilia and the clear fluid portion of the protoplasm of the living organisms are quite unstained.

The staining of marine eggs is essentially similar to the staining of Paramoecium. Owing to the presence of bicarbonates and phosphates in sea water considerably more acid must be added, than is necessary to change the color of neutral red from yellow to red, before all the dye is actually in the acid condition and consequently, before the dye will fail to enter the eggs. About $0.5 \mathrm{cc}$. $\frac{\mathrm{N}}{\mathrm{T}} \mathrm{HCl}$ to $100 \mathrm{cc}$. sea water is sufficient to bring about 

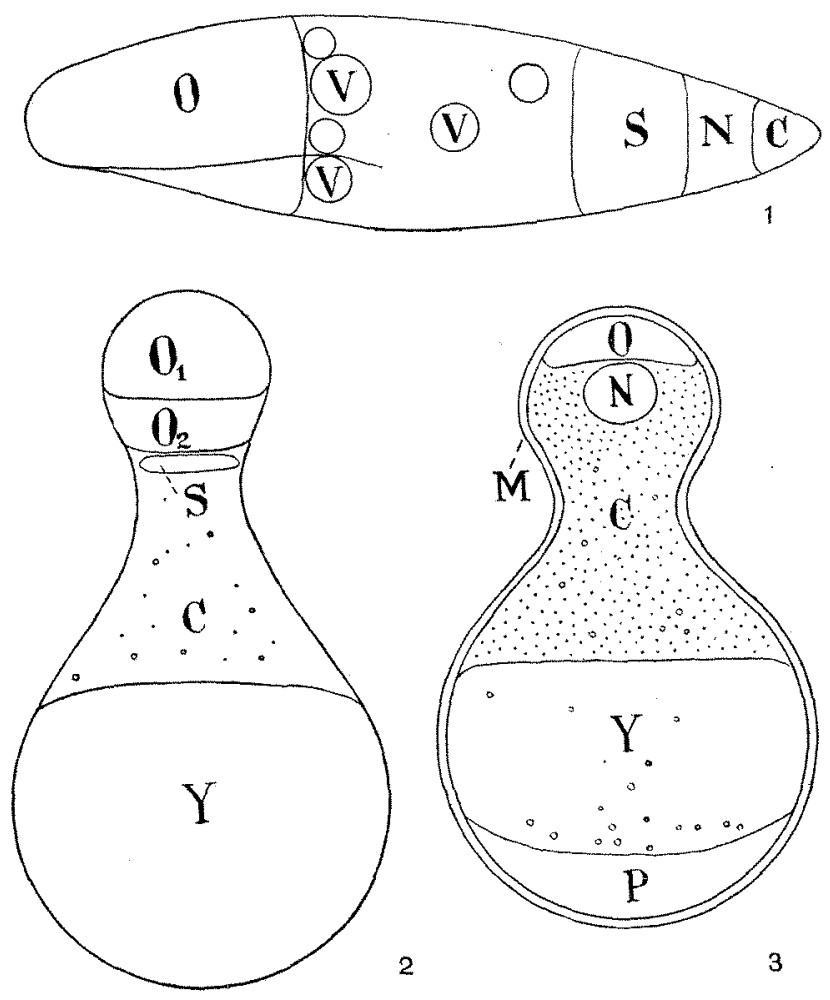

Fig. 1 Diagram of the areas which may be distinguished in a centrifuged Paramoecium, (electric centrifuge 1.5 hours at a radius of $6 \mathrm{~cm}$.) stained in neutral red.

$O$, oil (?) globules; V, food vacuoles, the contained matter often red stained; $\mathrm{S}$, granules stained in neutral red; $\mathrm{N}$, macronucleus; $\mathrm{C}$, crystals. If the organism is uninjured, there is a very rapid redistribution of substances in the protoplasmic circulation.

Figs. 2 and 3 Diagrams of the distribution of substances in centrifuged Chaetopterus (2) and Arbacia (3) eggs stained in neutral red. Elongation in the axis of the force has taken place. $\mathrm{O}, \mathrm{O}_{1}, \mathrm{O}_{2}$, oil globules; in Chaetopterus of two sizes and of two densities $\mathrm{O}_{1}$ and $\mathrm{O}_{2} ; \mathrm{N}$, nucleus; $\mathrm{C}$, clear area; in Chaetopterus containing a few scattered yolk and minute red stained granules; in Arbacia containing at the surface a few pigment bodies (chro matophores) and numerous minute stained granules, quite unmoved by the cent rifuge. At the time of fertilization these disappear, apparently going to form the substance which passes out of the egg and hardens to a fertilization me mbrane. $\mathrm{X}$, yolk; in Chaetopterus appearing pink from numerous minute red stained granules most of which collect in a mass (S) just under the oil. $P$, the pigment granules, appearing dark red from absorntion of the neutral red dye. 
the color change of neutral red. The yellow color returns to some extent on standing. Both Arbacia and Asterias eggs stain in $100 \mathrm{cc}$. sea water $+2 \mathrm{cc} . \frac{N}{10} \mathrm{HCl}$ but fail to stain if $3 \mathrm{cc} . \frac{\mathrm{N}}{10}$ $\mathrm{HCl}$ is added, even after one hour. They are quite transparent and uncoagulated. About half the egg of Asterias coagulate in $100 \mathrm{cc}$. sea water $+5 \mathrm{cc} \cdot \frac{\mathrm{N}}{10} \mathrm{HCl}$ after one hour's time and those which are opaque and coagulated become faint pink in color. Apparently the dye is adsorbed by the proteid coagulum.

The mechanism of absorption of neutral red is practically the same as in Paramoecium. In all the eggs thus far studied (Cumingia, Arbacia, Asterias, Toxopneustes, Hipponoë, Holothuria and Chaetopterus) it combines with very definite granules which often differ in color, always in specific gravity and generally in size, from other granules in the egg. In markedly pigmented eggs like Arbacia or Cumingia, it is the pigment granules which become stained, but in the eggs of Holothuria, the large yolk granules are orange and the dye absorbing granules are small and colorless. The latter are much the heaviest granules present and pass to the outer pole of the egg when centrifuged. That this is not due to an increase in weight from taking up of the dye may be shown by first centrifuging the eggs and then staining them. Exactly the same areas stain as if the experiment had been reversed, the eggs first stained and then centrifuged.

The two statements made above are true of all the eggs studied except Chaetopterus. The stainable granules of Chaetopterus are specifically different from other granules in the egg, but they are not the heaviest. The difference is best made clear by reference to figs. 2 and 3.

The red area is found to be just under the oil and to consist of globules of varying size which have apparently been formed by fusion of very minute red granules. These may be easily seen over the clear area and scattered throughout the yolk mass, giving a pinkish tinge to that region.

A similar aggregation of minute granules to form larger granules occurs in Toxopneustes also. Both fertilized and unfertilized eggs at first stain 'diffusely,' i.e., the dye is localized in very minute granules, visible under high magnification. More and more of 
these minute granules take the dye and at the same time fuse together to form clearly defined red bodies much like the chromaphores of Arbacia eggs. The final stage is more rapidly attained in eggs with fertilization or artificial membranes. Inasmuch as the conditions under which the dye unites with the granules in the two types of eggs, fertilized and unfertilized, may be different, we cannot at present draw conclusions as to differences in permeability to dyes in the two types of eggs.

In brief the mechanism of staining Paramoecium or marine eggs is as follows: The dye enters the egg as the weak base, yellow in color, and combines with a specific insoluble substance present, in the form of granules. The combination resulting, likewise insoluble and comparable to a salt, is red in color just as are the water soluble salts of neutral red. The exact chemical nature of the granules with which neutral red combines is unknown.

\section{THE PENETRATION OF ALKALIES}

\section{Method and previous results}

Of the many methods which may be used in studying the penetration of various substances, the color change of an indicator within the cell is the simplest and most delicate for the detection of acids and alkalies. Many plant cells contain natural pigments which may serve as indicators. Both Pfeffer and DeVries made use of such pigments in their studies on permeability.

DeVries (71, p. 24) noted that the red sap of beet cells becomes brown to yellow brown in dilute $\mathrm{NH}_{4} \mathrm{OH}$ and the red color comes back again on washing in pure water.

Pfeffer ('77, p. 140) showed that the red sap of Pulmonaria petals and of the stamen hairs of Tradescantia becomes first blue then greenish in dilute ammonia. $\mathrm{KOH}$ and $\mathrm{K}_{2} \mathrm{CO}_{3}$ act like ammonia (p. 141). Pfeffer regards the dead and the living plasma to be similarly easily permeable for dilute alkalies as well as acids. This is the view stated in botanical text-books at the present day and the subject is dismissed with few words and without further

THE JOUKMAL OF EXPERMENTAL zOÖLOGY, vol. 10, No. 4 
comment. Evidence will be given in the body of this paper to show that the generally accepted view is only in part the truth, so far at least as the penetration of alkalies is concerned.

Animal cells suitable for experimental studies contain no pigment exhibiting a marked color change in alkalies. We may overcome the diffiulty by introducing a dye which does so change. Neutral red is excellent for the purpose. In solution, it turns from red to yellow in an $\mathrm{H}$ ion concentration of $1.10^{-7}$ to $1.10^{-8}$, and is perfectly harmless for the cells providing they are not allowed to take up over a certain maximal amount. For the sake of comparison neutral red was employed in plant cells as well.

I have endeavored to answer for the alkalies the following general questions, many of which have already been settled for other classes of substances by previous workers in the field of cell permeability.

1. Do plant and animal cells exhibit essentially similar permeability relations for alkalies?

2. Do living and dead cells exhibit similar permeability relations for alkalies?

3. Are there distinct classes of alkalies in regard to permeability?

4. Are the effects of different alkalies reversible or irreversible after an equal amount ( $\mathrm{OH}$ ion concentration) has entered the cell?

5. May the composition of the medium affect permeability without irreversibly injuring the cells themselves?

6. Are there any relations between functional changes and permeability for alkalies?

7. May alkalies produce marked functional changes without entering the cell?

Many of these questions can be decided only with an especially favorable type of cell and the evidence one way or the other has therefore been given in describing the permeability phenomena of that particular cell. The connection between the penetrating power and the physical properties of the various alkalies are taken up in the discussion. I have taken the greatest precaution to 
exclude sources of error and make sure that the permeability of living cells is in reality the problem studied, a point not always carefully guarded against. For this reason the observations and experiments which follow are recorded in considerable detail.

\section{Objections to the use of an indicator within the cell}

Despite the fact that indicators offer the most delicate means of detecting alkalies (and neutral red is exceedingly sensitive in this respect, reacting to $\mathrm{Na}_{2} \mathrm{HPO}_{4}$, there are four possible complications arising from its use in the cell, all of which would tend to make the amount of alkali entering, appear less than that which actually entered. Or, to put it in another way, more alkali would enter than we should calculate, judging from the concentration at which the color change takes place in pure water.

1. In determining alkalinity in a test tube we have only a very weak solution of the indicator; in the leaf cells of Elodea, neutral red is in concentrated solution (otherwise it would be quite invisible in so narrow a space) and also in combination with some complex organic acid. Enough alkali must enter to convert it all into the free base $(\mathrm{ROH})$ before the color change occurs.

2. In Spirogyra neutral red is accumulated as a tannin compound which becomes straw color in the presence of alkali and red again on adding acid and begins to dissolve. This compound as well as the combination formed by neutral red with the granuules of animal cells require a greater concentration of alkali or a longer time, to turn them yellow than does the pure dye in distilled water. By treating cells with chloroform or by rupturing their surface, as described under each organism investigated, it is possible to exclude the complication due to the above mentioned conditions. The concentration of alkali may be found which brings about a color change instantaneously.

3 . The most serious objection to the use of neutral redas an indicator within the cell is, as I have determined experimentally, that in the presence of proteids like egg albumen, the dye (in solution) is unaffected by a certain amount of added alkali which 
apparently enters into combination with the albumen. The following experiment illustrates this:

A stock solution of unknown strength in $0.1 \mathrm{~N} \mathrm{NaCl}$ was made from Merck's powdered egg albumen. When filtered it was opalescent.

To 5 ce. was added one drop of 0.05 per cent neutral red and the solution titrated with $\frac{N}{50} \mathrm{KOH}$. $0.6 \mathrm{cc}$. was added before the original pink color began to turn and $0.9 \mathrm{cc} . \frac{\mathrm{N}}{5} \mathrm{KOH}$ before it was yellow. Phenolpthalein was then added and the solution found to be neutral. In all $1.6 \mathrm{cc}$. was added before the phenolpthalein began to turn pink and $2.0 \mathrm{cc}$. before it became distinctly pink.

0.6 cc. $50 \mathrm{NH}_{4} \mathrm{OH}$ was also required before the neutral red began to fade and $1.1 \mathrm{cc}$. before a distinct yellow appeared. The solution was still neutral to phenolpthalein and 3.00 cc. were required before a light pink appeared.

The effect of chloroform on the power of neutralization was also determined. The solutions compared were:

A 5 cc. albumen +10 ce. water +1 drop 0.1 per cent neutral red.

B 5 cc. albumen $+10 \mathrm{cc}$. chloroform-saturated water +1 drop 0.1 per cent neutral red.

Exactly the same amounts of $\frac{\mathrm{N}}{50} \mathrm{KOH}$ and $\frac{\mathrm{N}}{50} \mathrm{NH}_{4} \mathrm{OH}$ were required to induce the color change in $A$ as in $B$. Chloroform has no effect on the combining power.

Yet one drop $\left(0.05\right.$ cc.) of $\frac{\mathrm{N}}{50} \mathrm{KOH}$ or $\mathrm{NH}_{4} \mathrm{OH}$ is more than sufficient to render $0.1 \mathrm{~N} \mathrm{NaCl}$ solution alkaline to both neutral red and phenolpthalein.

Any difference in permeability between $\mathrm{KOH}$ and $\mathrm{NH}_{4} \mathrm{OH}-$ and there is a very great difference-cannot therefore be attributed to a difference in combining power of $\mathrm{K}$ and $\mathrm{NH}_{4}$. The use of chloroform in killing cells must affect the surface layer of the cell in some way, and not the combining power of the cell proteids within.

4. It is quite possible that the cell (especially plant cells) may actively secrete an acid which neutralizes the alkali as it enters. But when we consider that the mass of the material studied relative to that of the alkaline solution is very small and that the 
$\mathrm{KOH}$, let us say, would continue to diffuse in so long as neutralized at a practically constant rate, it would require an enormous production of acid on the part of the cell to take care of the $\mathrm{KOH}$ entering. For this reason alone it seems safer to consider that the inorganic alkalies do not enter (without affecting the surface membrane) rather than that they are neutralized as they enter.

There is, indeed, some evidence that an acid is secreted into the vacuole of Elodea cells. If red stained leaves are placed in $\frac{N}{40}$ $\mathrm{NH}_{4} \mathrm{OH}$ until color change occurs and then are immediately transferred to pure water, the cells are uninjured and the red color returns. It is often a distinctly brighter red than before. I have never noticed that Elodea cells placed in solutions of inorganic alkalies became a brighter red before the color change finally occurred.

Again red stained leaves treated for one minute with chloroform water appear a slightly brighter red than the control. The chloroform apparently induces the formation of an acid which collects in the vacuole. Yet such leaves placed in $\frac{\mathrm{N}}{40} \mathrm{NH}_{4} \mathrm{OH}$ are decolorized slightly more rapidly than normal leaves and in $\frac{N}{40}$ $\mathrm{KOH}, 30-40$ times more rapidly. The experiment shows the negligible effect of the acid in neutralizing entering alkali.

The above considerations make the calculation of the strength of any alkali entering a cell very difficult. We can state this much, however, we can give the concentration of alkali in terms of the color change of the neutral red combination in each particular cell, and the relation of this color change to structural or functional changes brought about by the presence of the alkali. We must assume that when red becomes yellow the $\mathrm{OH}$ ion concentration of the various alkalies is equivalent.

It must be borne in mind that the indicator in both Spirogyra and Elodea is in the cell vacuole and that the alkali to reach it must pass through the cell (plasma) membrane, the protoplasm, and the vacuolar membrane. On the contrary, the indicator in animal cells is in the protoplasm. 


\section{Experiments with plant cells}

a. Strongly dissociated alkalies: The leaf of Elodea, except at the midrib, is only two cells thick, a layer of small cells constituting the lower surface, a layer of much larger cells above. There is great variation in different leaves in the time for the color change to take place, as well as individual differences among the separate cells. A consequence of the latter fact is the decolorization (in $\mathrm{K}, \mathrm{Na}$, or $\mathrm{N}\left(\mathrm{C}_{2} \mathrm{H}_{5}\right)_{4} \mathrm{OH}$ ) of the leaf in patches, groups of red cells becoming yellow before others. The phenomenon is not marked in $\mathrm{Ca}, \mathrm{Sr}$, and Ba. Spirogyra exhibits the same variability as Elodea.

A comparison between the inorganic hydroxides was made with $\frac{\pi}{40}$ alkali in tightly corked bottles, to prevent absorption of $\mathrm{CO}_{2}$. The water was redistilled from glass and was non-toxic to Spirogyra, Elodea and Paramoecium. Paramoecium is especially sensitive to commercial distilled water and may be used as an indicator of the purity of a water. Elodea showed rotation in commercial distilled water after 24 hours. Nevertheless the rate of entrance of $\mathrm{NaOH}$ is more rapid when dissolved in commercial distilled water than in pure redistilled water and more rapid in pure redistilled water than in tap water.

The following table constructed from many experiments gives the relative rate of penetration of $\mathrm{N}\left(\mathrm{C}_{2} \mathrm{H}_{5}\right)_{4} \mathrm{OH}, \mathrm{Na}, \mathrm{K}, \mathrm{Ca}, \mathrm{Sr}$, and $\mathrm{Ba}$ hydroxides. The actual times varied somewhat in individual experiments, but the relation order of penetration was

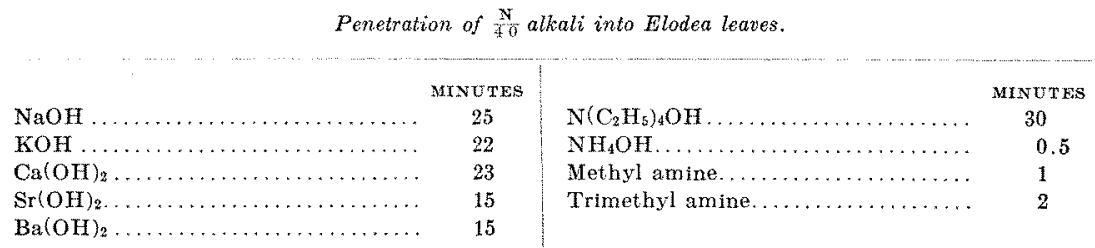

s I am indebted to the Chemistry Department of Columbia University for methyl, dimethyl, trimethyl, ethyl, propyl, and isopropyl amines. Tetraethylammonium hydroxide was obtained from Merck and Co. The inorganic hydroxides were Eimer and Amend's C. P. with the exception of $\mathrm{Ba}(\mathrm{OH})_{2}$, which was manufactured by Kahlbaum. 
fairly constant. In all the experiments on alkalies, $\mathrm{N}$ means normal, equivalent to corresponding normal solutions of HCL.

The rate of entrance when the cells have been killed in various ways is shown in tables 2 and 3 .

TABLE 2

Times for different concentrations of $\mathrm{NaOH}$ to decolorize the neutral red tannin compound within Spirogyra threads. In column $A$ are figures for the living plant; in $B$ for threads killed by boiling water and stained in neutral red; in $C$ for threads killed by $\mathrm{N}$ HCL (3 mins.) and.washed free of acid; in $D$ killed by $\mathrm{CHCl}_{3}$ water (1 min.), and in $\mathrm{E}$ the threads were killed by a saturated solution of $\mathrm{HgCl}_{2}$ (3 mins.) and washed in water. The $\mathrm{NaOH}$ was dissolved in tap water and the solutions tested in corked bottles.

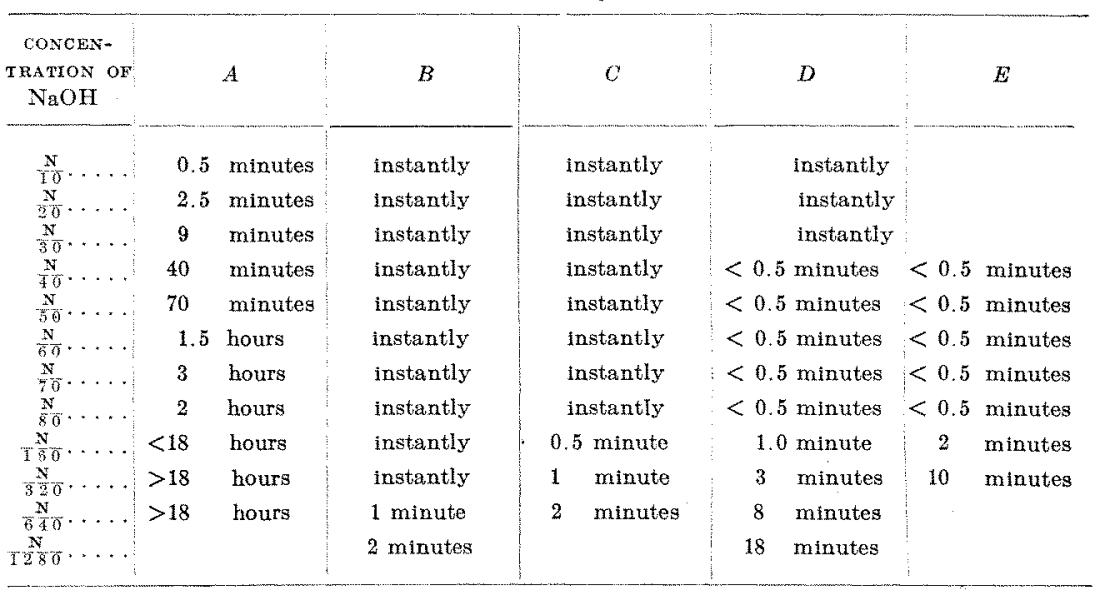

TABLE 3

Penetration of different concentrations of $\mathrm{NaOH}$ into Elodea leaves. The $\mathrm{NaOH}$ was dissolved in tap water.

\begin{tabular}{|c|c|c|c|}
\hline $\begin{array}{c}\text { CONCENTRATION } \\
\text { OF } \\
\mathrm{NaOH}\end{array}$ & NORMAL LEAVES & $\begin{array}{l}\text { LEAVES KILLAD } \\
\text { BY CHLOROFORM }\end{array}$ & $\begin{array}{l}\text { LEAVES KKLLLED BT BOIL- } \\
\text { ING WATER, AND DEEPLY } \\
\text { STAINED IN NEUTRAIS RED }\end{array}$ \\
\hline 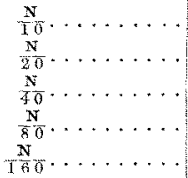 & $\begin{array}{c}2 \text { minutes } \\
9 \text { minutes } \\
45 \text { minutes } \\
3 \text { hours } \\
\text { unaffected after } 18 \text { hours }\end{array}$ & $\begin{array}{l}\text { instantly } \\
1 \text { minute } \\
2 \text { minutes } \\
5 \text { minutes } \\
8 \text { minutes }\end{array}$ & $\begin{array}{l}\text { instantly } \\
\text { instantly } \\
\text { instantly } \\
\text { instantly } \\
2 \text { minutes }\end{array}$ \\
\hline
\end{tabular}

It is found that all alkalies may enter with practically no resistance providing the cell surface has been destroyed in some way; it is immaterial how. Thus in $\frac{\mathrm{N}}{80} \mathrm{NaOH}$ Spirogyra threads retain their red color about 3.5 hours, but if treated with $\mathrm{CHCl}_{3}$ 
saturated water and then placed in $\frac{\mathrm{N}}{80} \mathrm{NaOH}$ the red precipitate becomes yellow immediately. On adding dilute $\mathrm{HCl}$ the thread again becomes red and the precipitate begins to dissolve.

As shown above, chloroform has no effect on the alkali combining power of egg albumen and presumably none on cell proteids. It must be that the inability of the alkali to enter is due rather to the inability to pass the surface layer of the Spirogyra cell than to a neutralization by proteid or acid after passing this layer.

The color change in the tannin precipitate takes place practically instantaneously in $\frac{x}{640} \mathrm{NaOH}$ (or $\mathrm{KOH}, \mathrm{Ca}(\mathrm{OH})_{2}, \mathrm{Ba}-$ $(\mathrm{OH})_{2}$ or $\mathrm{Sr}(\mathrm{OH})_{2}$ ), if we cut the cell transversely so as to allow ready mixture of solution and precipitate. In weaker concentrations the color change also occurs but it takes a much longer time. Thus, dead Spirogyra filamants (red stained) become decolorized in less than 15 hours in $\frac{\pi}{512} \mathrm{NaOH}$, while the control in water remained red.

Every cell which I have tested (Cabomba rosafolia, containing a natural red pigment, Elodea Canadensis, Spirogyra, Paramoecium, Vorticella and various marine eggs) has proved to be resistant to the entrance of the inorganic hydroxides, a condition which is lost on death (by chloroform, $\mathrm{HCl}$, heat coagulation, drying, etc.) This post-mortem increase of permeability has been so often emphasized by many writers for very diversesubstances that it hardly requires special confirmation for the alkalies, except as showing the degree of impermeability which the normal living cell possesses.

b. Weakly dissociated alkalies:-Exactly opposite results are obtained when ammonia and its primary, secondary and tertiary alkyl substitution products ${ }^{5}$ are studied, instead of the inorganic hydroxides. All these substances pass into the cell with very little if any resistance. Elodea is more suited to experimentation than Spirogyra ${ }^{6}$ because the color change is more marked (tables 4 and 5 ).

${ }^{6}$ If a red stained filament of Spirogyra is placed $\frac{\mathrm{N}}{40} \mathrm{NH}_{4} \mathrm{OH}$ it becomes dark green in one minute. On washing in water the red color soon returns. In weaker solutions of ammonia the formation of the $\mathrm{NH}_{4}$-tannate compound prevents a sharp color change in the neutral red-tannate compound. 
TABLE 4

Effect of $\mathrm{NH}_{4} \mathrm{OF}$ on red Elodea leaves. Glass distilled water used. Solutions in corked bottles

\begin{tabular}{|c|c|c|c|c|c|c|c|c|}
\hline $\begin{array}{c}\text { CONCENTRA- } \\
\text { TION OF } \\
\mathrm{NH}_{4} \mathrm{OH}\end{array}$ & $\frac{N}{17}$ & $\frac{N}{20}$ & $\frac{\mathrm{N}}{40}$ & $\frac{N}{80}$ & $\underset{1+60}{N}$ & 35 & $\frac{N}{4}$ & $T \frac{N}{2} \overline{8} 0$ \\
\hline Normal leat. & instantly & 1 minute & 1 minute & $1 \frac{1}{2}$ minute & 3 minutes 6 & 6 minutes & $\begin{array}{l}\text { Not entire- } \\
\text { Iy yellow } \\
\text { after } 30 \\
\text { minutes }\end{array}$ & $\begin{array}{l}\text { Unaffected } \\
\text { after } 1 \\
\text { hour. } \\
\text { Slightly } \\
\text { affected } \\
\text { after } 18 \\
\text { hours }\end{array}$ \\
\hline $\begin{array}{l}\text { Chloroform } \\
\text { treated leaf. }\end{array}$ & Instantly & instantly & 3 minute & 1 minute & 3 minutes & 6 minutes & $\begin{array}{l}\text { Dye diffuses } \\
\text { out of leaf }\end{array}$ & \\
\hline
\end{tabular}

In Spirogyra, entrance of ammonia may be indicated also by the precipitation of tannin, and this method has been used by Overton ('97) who found that ammonia, the primary and secondary amines penetrate readily, the tertiary amines and quaternary ammonium bases do not, behaving in this respect like inorganic hydroxides. So far as I have observed trimethyl amine enters cells readily but not so quickly as the methyl or dimethyl derivitives of ammonia.

If an Elodea leaf has remained in a solution of $\frac{\mathrm{N}}{40} \mathrm{NaOH}$ (or $\mathrm{K}, \mathrm{Ca}, \mathrm{Sr}, \mathrm{Ba}, \mathrm{N}\left(\mathrm{C}_{2} \mathrm{H}_{5}\right)_{4}$ hydroxides of any concentration) until the color change to yellow has occurred, and then is immediately placed in pure water it is found that the leaf has been killed and the red color never returns. ${ }^{7}$ The capacity of again accumulating dye is likewise lost. The entrance of a sufficient quantity of inorganic alkali to affect the neutral red produces irreversible changes in the cells themselves.

But if a similar Elodea leaf is placed in an $\frac{\pi}{40} \mathrm{NH}_{4} \mathrm{OH}$ solution the color change occurs almost instantly (about one minute). Furthermore, on transferring to pure water, the red color in the cells and the protoplasmic rotation characteristic of the plant returns. Evidently death of the leaf does not necessarily ensue from the

'Exeept on immediately adding an acid. This shows that the dye is actually changed to yellow and not reduced to a colorless substance. The actual yellow color may be obseured to some extent by the green chlorophyll present. 
entrance of a concentration of $\mathrm{OH}$ ions sufficient to affect the neutral red combination. In the case of the inorganic alkalies and $\mathrm{N}\left(\mathrm{C}_{2} \mathrm{H}_{5}\right)_{4} \mathrm{OH}$ death is to be referred to two possible causes.

First, and of greatest importance, the alkali only enters after the cell surface has been destroyed. This is best illustrated by comparison of the mode of entrance of $\mathrm{NH}_{4} \mathrm{OH}$ and $\mathrm{NaOH}$ into Paramoecium (p.546) and is strong evidence in support of Hoeber's ('06, pp. 260, 266-267) theory that the strong electrolytes, in general, produce their effects by a change in the colloids of the cell surface and not of the cell interior.

Second, the combination of the strong alkalies with the cell surface proteids may be irreversible, whereas the combination of the weak ammonia is easily reversible.

The cell surface of the living as compared with the dead (by chloroform treatment) cells offers a highly resistant barrier to the entrance of the strong alkalies but both living and dead cells are almost equally permeable for the weak alkalies (see table 4). This suggests, but does not prove, that if small quantities of $\mathrm{NaOH}$ could enter without affecting the membrane, the cell would be as unharmed as in $\mathrm{NH}_{4} \mathrm{OH}$.

Ammonia has likewise a toxic effect but it is only manifest after a longer exposure, and is quite independent of the entrance of ammonia into the cell. Red Elodea leaves recover if placed in fresh water immediately after decolorization in $\frac{\mathrm{N}}{10} \mathrm{NH}_{4} \mathrm{OH}$. If left for five minutes the dye becomes red again but the cells eventually die. If left over 30 minutes even the red color fails to return. The leaf is of course killed.

The inorganic hydroxides (and $\mathrm{N}\left(\mathrm{C}_{2} \mathrm{H}_{5}\right)_{4} \mathrm{OH}$ ) only enter the cell after they have affected the normal impermeability -in other words after they have rendered its surface permeable to themselves. It seems best, then, to speak of a resistance of the cells for the strong and a permeability of the cell for the weak alkalies.

Reversibility of the neutral red color change is quite independent of the death of the cell. The red returns after decolorization by the amines although they produce fatal after-effects.

It likewise returns in cells first decolorized in ammonia and then killed with chloroform water, and more rapidly than in the 
control. Chloroform water induces the formation of an acid in the vacuole and the production of acid in solution of weak alkalies is probably one factor in the return of the red color.

Failure of Elodea leaves to become red when once turned yellow by $\mathrm{KOH}$ is not due to the longer time required by the $\mathrm{KOH}$ to bring about the color change (the neutral red diffusing out slowly in the interval), because the leaves become yellow within one minute, if placed in $\frac{N}{10} \mathrm{KOH}$ yet in pure water the red does not return.

We must seek an explanation of the reversibility of the $\mathrm{NH}_{4} \mathrm{OH}$ change, the irreversibility of the $\mathrm{KOH}$ change in the different degrees of hydrolytic splitting of the respective $\mathrm{NH}_{4}$ and $\mathrm{K}$ salts of the acid with which the neutral red combines. If $R$ is the acid radical within the plant and $D$ the neutral red radicle, the reactions may be represented thus:

$$
\begin{gathered}
\mathrm{RCOOH}+\mathrm{DOH}=\mathrm{RCOOD}+\mathrm{H}_{2} \mathrm{O} . \\
\mathrm{RCOOD}+\mathrm{NaOH}=\mathrm{RCOONa}+\mathrm{DOH} \\
\mathrm{RCOOD}+\mathrm{NH}_{4} \mathrm{OH}=\mathrm{RCOONH}_{4}+\mathrm{DOH}
\end{gathered}
$$

The $\mathrm{RCOONH}_{4}$ salt of a weak base and a weak acid undergoes a greater hydrolytic splitting than the RCOONa combination, the $\mathrm{NH}_{4} \mathrm{OH}$ formed diffuses rapidly away and recombination of $\mathrm{RCOOH}$ and $\mathrm{DOH}$ again take place.

The difference in resistance of the plasma membrane to $\mathrm{NH}_{4} \mathrm{OH}$ and $\mathrm{NaOH}$ is strikingly shown in the following experiment. If we remove Elodea leaves, after decolorization in $\mathrm{NH}_{4} \mathrm{OH}$ to chloroform water (one minute) and then place them in ${ }_{50}^{x} \mathrm{NaOH}$ there is never a return of the red color. Chloroform destroys the plasma membrane and the $\mathrm{KOH}$ may penetrate rapidly. On the other hand, if the leaf decolorized in $\frac{\mathrm{N}}{40} \mathrm{NH}_{4} \mathrm{OH}$ is placed in $\frac{\pi}{50} \mathrm{NaOH}$, without previous chloroform treatment, its cells become red again just as they would in pure water. The conditions for demonstrating any entrance of $\mathrm{NaOH}$ are here most favorable, the neutral red is already in the alkaline condition, the proteids have taken up the amount of $\mathrm{NH}_{4} \mathrm{OH}$ necessary before and alkaline reaction may be indicated, yet the $\mathrm{NH}_{4} \mathrm{OH}$ diffuses rapidly 
outward while the $\mathrm{NaOH}$ cannot pass in to maintain the dye in the yellow condition. Eventually of course the leaf in $\frac{\mathrm{N}}{50} \mathrm{KOH}$ becomes yellow just as does the control.

The amines show a behavior similar to $\mathrm{NH}_{4} \mathrm{OH}$ but, with the exception of trimethyl amine, are considerably more toxic and produce after effects which lead to the death of the cell. The entrance of just enough to affect the neutral red is typically fatal (table 5).

\section{TABLE $\tilde{0}$}

Effect of $\mathrm{NH}_{4} \mathrm{OH}$ and amines on red Elodea leaves. Concentration, $\frac{\mathrm{N}}{40}$ in glass distilled water. The red color disappears (decolorized) in less than 2 minutes in all solutions. The leaves are then transferred to $(A)$ tap water; $(B) \frac{\mathrm{N}}{\mathrm{I} 5 \mathrm{~N}} \mathrm{NaOH}$. Columns $A$ and $B$ give the results, respectively.

\begin{tabular}{|c|c|c|}
\hline$\frac{N}{40}$ & $A$ & $B$ \\
\hline $\mathrm{NH}_{4} \mathrm{OH} \ldots \ldots$ & $\begin{array}{l}\text { Cells become red in } 15-30 \mathrm{~min}- \\
\text { utes and still alive after } 18 \mathrm{hrs} \text {. }\end{array}$ & $\begin{array}{l}\text { Cells become red again in } 15-30 \\
\text { mins. and only turn yellow } \\
\text { when control turns yellow }\end{array}$ \\
\hline $\mathrm{NH}_{3} \mathrm{CH}_{3} \mathrm{OH}$. & $\begin{array}{l}\text { Cells become red in } 15-30 \text { min- } \\
\text { utes but dye diffuse out. } \\
\text { Colorless after } 18 \text { hours. }\end{array}$ & Cells remain colorless \\
\hline $\mathrm{NH}_{2}\left(\mathrm{CH}_{3}\right)_{2} \mathrm{OH}$ & $\begin{array}{l}\text { Cells become red in } 15-30 \text { min- } \\
\text { utes but dye diffuse out. } \\
\text { Colorless after } 18 \text { hours. }\end{array}$ & Cells remain colorless \\
\hline $\mathrm{NH}\left(\mathrm{CH}_{s}\right)_{3} \mathrm{OH}$ & Same as $\mathrm{NH}_{4} \mathrm{OH}$ & Same as $\mathrm{NH}_{4} \mathrm{OH}$ \\
\hline $\mathrm{NH}_{3}\left(\mathrm{C}_{3} \mathrm{H}_{5}\right) \mathrm{OH}$ & Same as $\mathrm{NH}_{3} \mathrm{CH}_{3} \mathrm{OH}$ & Same as $\mathrm{NH}_{3} \mathrm{CH}_{3} \mathrm{OH}$ \\
\hline $\begin{array}{l}\mathrm{NH}_{2}\left(\mathrm{C}_{2} \mathrm{H}_{5} \mathrm{CH}_{2}\right) \mathrm{OH} \ldots \ldots \ldots \\
\text { (normal propyl amine) }\end{array}$ & Same as $\mathrm{NH}_{3} \mathrm{CH}_{3} \mathrm{OH}$ & Same as $\mathrm{NH}_{3} \mathrm{CH}_{3} \mathrm{OH}$ \\
\hline $\begin{array}{c}\mathrm{NH}_{3}\left(\mathrm{CH}_{s}\right)_{2} \mathrm{CHOH} \text { (1sopropyl- } \\
\text { amine }) \ldots \ldots \ldots \ldots \ldots \ldots\end{array}$ & Same as $\mathrm{NH}_{3} \mathrm{CH}_{3} \mathrm{OH}$ & Same as $\mathrm{NH}_{3} \mathrm{CH}_{3} \mathrm{OH}$ \\
\hline Control. & Red and normal after 18 hours & Red $>2$ hours \\
\hline
\end{tabular}

Leaves treated with $\mathrm{CHCl}_{3}$, after decolorization in any of the above solutions, and placed in $\frac{\mathrm{N}}{10} \mathrm{NaOH}$ never become red again; if placed in tap water all terd to become red but the red dye eventually diffuses out of the cells because the cell surface has been affected by the chloroform.

c. Permeability of cells exhibiting protoplasmic rotation. There appears to be no marked difference in the resistance of 'rotating' and quiescent cells to the penetration of $\mathrm{NaOH}$ or $\mathrm{KOH}$. In a number of experiments in which individual cells were watched rotating cells became yellow before non-rotating or vice versa. Comparisons of whole leaves are not of much value because of their great variability in resistance to $\mathrm{NaOH}$. 
Judging from Hörmann's ('98) researches and the comparison he has drawn between the rotating plant protoplast and muscular contraction a difference in permeability was to be looked for. The cessation of streaming induced by thermal, mechanical, chemical and electrical means strongly suggests that a shockstoppage is comparable to muscle contraction and depends on a similar conditioning change. Even the details connected with electrical stimulation run parallel. According to Hörmann the passing of a constant current through a rotating Nitella cell causes a cessation of movement at the cathode on the make and at the anode on the break. While the current is passing the streaming is slower at the cathode. A wave of shock stoppage may be propagated from one region of a leaf to another and when tested electrically the stopped regions are found to be negative to rotating ones just as the region of a muscle in contraction is negative to an uncontracted area.

We might therefore consider that protoplasmic streaming is in some way connected with a high degree of electrical polarization, a low surface tension and a surface membrane relatively impermeable to soluble substances, states typical of the resting condition of many types of cells. Each of these three conditions undergoes a change in the opposite direction, on 'stimulation' of the cell.

As stated before I have been unable to detect any constant differences in permeability (or resistance) of rotating and nonrotating cells to $\mathrm{KOH}$ or $\mathrm{NaOH}$. It is quite possible that several factors each of which alone may be sufficient to prevent rotation, are involved.

d. The concentration of alkali which stops rotation:- $-\mathrm{In} \mathrm{NH}_{4} \mathrm{OH}$ $\left(\frac{\mathrm{N}}{10}\right.$ to $\frac{\mathrm{V}}{80}$ ) rotation ceases just at the point where the bright pink sap begins to turn dull pink before finally becoming yellow. In $\mathrm{NaOH}$ the rotation ceases, begins again and finally ceases permanently long before the initial dull pink of the color change appears. The description of the two experiments in which the changes in individual cells was observed is as follows: 
Ammonia: Red stained Elodea leaves are placed in $\frac{\mathrm{N}}{20} \mathrm{NH}_{4} \mathrm{OH}$. Cells become yellow in less than one minute. Rotation ceases at the time the color change begins $\left(\frac{3}{4} \mathrm{~min}\right.$.). After $1 \mathrm{~min}$. the alkali is replaced by water. The bright red color begins to return (20-25 mins.) and the cells are as red as they were originally in 1 hour. In 1 hour, 10 mins. jerky rotation begins and in 2 hours the original rapid rotation may be observed.

Sodium hydrate: Red stained Elodea leaves are placed in $\frac{N}{40} \mathrm{NaOH}$ under the microscope. Rotation ceases in about one minute, begins again slowly in 5-10 minutes, stops again after 15 minutes longer, and the red sap only begins to turn dull pink to yellow after 45 minutes to 1 hour. If the alkali is replaced by water, the sap never becomes red again and rotation never returns.

e. The effect of added substances on the penetration of $\mathrm{NaOH}$ and $\mathrm{KOH}$. As indicated in table 4 even chloroform treatment hardly increases the rate with which $\mathrm{NH}_{4} \mathrm{OH}$ may enter Elodea cells. Ammonia enters living cells as rapidly as dead ones. $\mathrm{NaOH}$ enters dead cells nearly as rapidly as ammonia, but living cells offer a high resistance to its passage. This resistance may be decreased by the addition of chloroform to the medium in amounts too small to have any irreversible effects in the absence of $\mathrm{NaOH}$. On comparing the time for $\mathrm{NaOH}$ or $\mathrm{KOH}$ to decolorize red stained Elodea leaves in $\frac{N}{40}$ solution alone and in $\frac{N}{4}$ solution plus dilute chloroform, alcohol, urea, glycerine, and various salts it is found that all have the effect of shortening the time which it takes for the $\mathrm{NaOH}$ to enter. The analysis of the experiment is somewhat complex. The effect of the added substance may be on the plasma membrane or on the alkali (affecting its dissociation or combining to form more toxic compounds); or the alkali may allow the more ready entrance of the added substance with co:sequent rapip destructive action and death of the cell which leads also to easy penetration of alkali. In other words, the action of two substances together may be additive.

On account of the complexity and difficulty of interpreting results I discontinued further experimentation along this line. A few experiments are given. The effect of dilute chloroform solution must be attributed to decrease in resistance of the cell 
surface. Such a concentration would have no effect on the alkali or vice versa.

If the urea glycerine or salts change the condition of the plasma membrane it is surprising how little effect this has on the protoplasmic streaming, which continues for many hours in solutions of these substances.

If leaves are selected from the same or neighboring whorls on the same plant concordant results may be obtained. But different plants and young and old leaves exhibit the greatest variations in resistance to $\mathrm{NaOH}$, as separate experiments will show. The solutions were contained in tightly corked glass vials to prevent absorption of $\mathrm{CO}_{2}$. Two to four leaves were tested in each experiment.

Experiment 1. A. $\frac{\mathrm{N}}{40} \mathrm{NaOH}, \frac{1}{6}$ saturated with $\mathrm{CHCl}_{3}$ tap water-decolorized in 13 minutes.

$B$. $\frac{\mathrm{N}}{40} \mathrm{NaOH}$ in tap water - decolorized in 90 minutes. Rotation ceases in leaves in this solution in $<15$ minutes, but if removed to tap water (after 15 minutes) begins again in 16-20 minutes.

C. $\frac{1}{6}$ saturated $\mathrm{CHCl}_{3}$ in tap water-Rotation ceases, but if removed to tap water (after 15 minutes,) begins again in < 15 minutes.

One-sixth saturated chloroform increases the permeability of Elodea cells to urea. Leaves removed from solution $\mathrm{C}$ after ten minutes plasmolyse much less readily than control leaves of the same plant in $\frac{\mathrm{K}}{2}$ urea.

Experiment 2. A. $\frac{x}{40} \mathrm{NaOH}+0.75 \mathrm{~m} \mathrm{C}_{2} \mathrm{H}_{5} \mathrm{OH}$ in tap water - decolorized in ten minutes.

B. $\stackrel{\stackrel{\mathrm{N}}{4} \mathrm{NaOH}}{40} \mathrm{Na} \mathrm{m} \mathrm{C}_{2} \mathrm{H}_{5} \mathrm{OH}$ in tap water-decolorized in 19 minutes.

C. $\frac{\mathrm{N}}{40} \mathrm{NaOH}$ in tap water-decolorized in 19 minutes.

D. $0.75 \mathrm{~m} \mathrm{C}_{2} \mathrm{H}_{5} \mathrm{OH}$ in tap water-rotation momentarily accelerated, then slowed and continued slow for $>1$ hour.

E. $0.37 \mathrm{~m} \mathrm{C}_{2} \mathrm{H}_{5} \mathrm{OH}$ in tap water-rotation hardly affected, slightly accelerated if anything.

Experiment 3. A. $\frac{\mathrm{N}}{40} \mathrm{NaOH}+0.075 \mathrm{~m} \mathrm{NaCl}$ in distilled water-decolorized in 4 minutes. 
B. $\frac{\mathrm{N}}{40} \mathrm{NaOH}$ in distilled water-decolorized in 28 minutes.

C. $0.075 \mathrm{~m} \mathrm{NaCl}$ in distilled water-rotation unaffected after 24 hours.

Experiment 4. In this experiment the effect of salts, and the penetration of $\mathrm{NaOH}$ into red stained Elodea and also Spirogyra were studied. The salt solutions are all in distilled water.

\begin{tabular}{|c|c|c|}
\hline & SPIROGXRA & ELODEA \\
\hline$\underset{+1)}{N}$ tap water $\mathrm{NaOH}$. & $\begin{array}{c}\min \\
30\end{array}$ & $\begin{array}{c}\min \\
45\end{array}$ \\
\hline No distilled water $\mathrm{NaOH}$. & 10 & 35 \\
\hline$\frac{\mathrm{N}}{40} \mathrm{NaOH}+\frac{\mathrm{N}}{10} \mathrm{NaCl} \ldots \ldots .$. & $\frac{1}{4}$ & 8 \\
\hline$\frac{\mathrm{N}}{40} \mathrm{NaOH}+\frac{\mathrm{N}}{T 0}\left(100 \mathrm{NaCl}+1 \mathrm{CaCl}_{2}\right)$ & 3 & 9 \\
\hline$\frac{N}{* 0} \mathrm{NaOH}+\frac{N}{10}(100 \mathrm{CaCl}+2.2 \mathrm{KCl}) \ldots$ & $\frac{1}{4}$ & 5 \\
\hline$\frac{N}{10} \mathrm{NaOH}+\frac{\mathrm{N}}{10}\left(100 \mathrm{NaCl}+2.2 \mathrm{KCl}+1.6 \mathrm{CaCl}_{2}\right)$ & 2 & 6 \\
\hline
\end{tabular}

Experiment 5.

\begin{tabular}{|c|c|c|}
\hline & SPIROGYRA & ELODEA \\
\hline$\frac{N}{40}$ tap water $\mathrm{KOH}$. & $\begin{array}{c}\min . \\
30\end{array}$ & $\begin{array}{c}\min . \\
35\end{array}$ \\
\hline$\frac{N}{40}$ distilled water $\mathrm{KOH}$. & 10 & 30 \\
\hline$\frac{N}{10} \mathrm{KOH}+\frac{\mathrm{M}}{8}$ glycerine in distilled water.. & 10 & 19 \\
\hline$\frac{N}{40} \mathrm{KOH}+\frac{\mathrm{M}}{4}$ glycerine in distilled water............... & 5 & 14 \\
\hline$\frac{\mathrm{N}}{40} \mathrm{KOH}+\frac{\mathrm{M}}{\mathrm{s}}$ urea in distilled water...... & 5 & 19 \\
\hline$\frac{N}{40} \mathrm{KOH}+\frac{\mathrm{M}}{4}$ urea in distilled water.. & 5 & 14 \\
\hline
\end{tabular}

Both the chloroform and alcohol in sufficient concentration allow the more ready entrance of $\mathrm{NaOH}$ (experiments 1 and 2). One-sixth saturated chloroform also retards plasmolysis by $\frac{\mathrm{M}}{2}$ urea. Such a retardation must be due to the fact that urea can enter chloroform cells more readily than normal cells. Urea penetrates normal cells slowly.

A most striking effect is exerted by the neutral salts on the penetration of $\mathrm{NaOH}$ (experiments 3 and 4), especially with Spirogyra. A concentration which may enter in distilled water only after 10 minutes, passes the cell membrane instantly in $\frac{N}{10}$ $\mathrm{NaCl}$. The effect on Elodea is similar. Addition of $\mathrm{CaCl}_{2}$ prevents the ready permeability to $\mathrm{NaOH}^{8}$. In Spirogyra the

${ }^{8}$ No precipitate of $\mathrm{CaCO}_{3}$ is formed. 
action is not marked but it is constant. It suggests that the effect of the pure $\mathrm{NaCl}$ is on the membrane, not on the $\mathrm{NaOH}$.

Lillie ('11) has held, and especially emphasizes this in a recent paper, that the action of a pure isotonic solution is to increase the permeability of the cells exposed to the action, and antitoxic cations as $\mathrm{Ca}$, prevent such an increase to a certain extent.

\section{Experiments with animal cells}

a. Paramoecium: Although several observers have investigated the toxicity of and physiological effect of the inorganic alkalies, no study of their power of penetrating animal cells has as yet been made. It is generally assumed in consequence of marked functional alterations produced that the cell is readily permeable for them. On the contrary the permeability relations have turned out to be exactly similar to those of plants. The same two classes of alkalies may be recognized, the weak $\left(\mathrm{NH}_{4} \mathrm{OH}\right.$ and amines) and the strong (inorganic hydroxides and $\mathrm{N}\left(\mathrm{C}_{2} \mathrm{H}_{5}\right)_{4}-$ $\mathrm{OH})$, the former meeting a very slight resistance, if any, the latter a marked resistance.

Neutral red was again made use of as an indicator. The Paramoecia were stained in a watch glass by adding just enough of the dye so that it is practically all taken up by them from solution. No abnormalities or functional changes appeared. If an excessive amount of neutral red is added the organisms cytolyse in a manner typical of $\mathrm{NH}_{4} \mathrm{OH}$ (see p. 543).

The fact that Paramoecium has a mouth through which alkali may enter introduces no error into the experiments, for the mouth is not open but the point at which vacuoles form is protected by a surface film. Its osmotic properties are unknown but most probably are essentially similar to those existing over the rest of the cell. The course of an experiment is often very short and the alkali is dissolved in distilled water in which there is no food to be eaten.

The change undergone by Paramoecium in alkalies is very similar to that which occurs when in the presence of a great many other toxic substances (alcohol, chloroform, chloretone, nicotin 
and other alkaloids, KCN and lack of oxygen (Budgett '98) and has been designated as cytolysis. An excellent account of the process is given by Wulzen ('09).

The essential effect is a change in shape, with the protrusion of clear drops (vesicles) from the surface and the separation of a more or less well defined membrane. On account of the change in shape (shortening and widening) it is difficult to say how much swelling accompanies cytolysis.

The exact changes vary somewhat according to the alkali and the strain of Paramoecium used, but the sequence is fairly constant, as follows:-

Motor reflex or avoiding reaction.

Change in shape.

Swim backward (not always observed).

Color change appears (with $\mathrm{NH}_{4} \mathrm{OH}$ ).

Swim slowly in circles without making headway.

Clear drops appear at surface.

Swimming ceases.

Drops fuse to a membrane. ${ }^{9}$

Surface bursts.

Color change appears (with $\mathrm{NaOH}$ ).

At a certain point the power of swimming is lost and at another point the red is changed to yellow and diffuses out of the cell. The relative times for these two events to take place is given in table 6 .

One drop of stained Paramoecia was mixed with $10 \mathrm{cc}$. of the alkaline solution in Syracuse watch glasses. A glass plate

9 'Membrane' is used in rather a broad sense. The type of membrane depends on the Paramoecium and on the alkali used. In $\mathrm{Ca}(\mathrm{OH})_{2}$ the clear drops extruded rarely fuse and no definite membrane forms. In $\mathrm{Ba}(\mathrm{OH})_{2}$ or $\mathrm{NaOH}$ an irregular membrane may form but I have never observed cilia beating on it. In $\mathrm{NH}_{4} \mathrm{OH}$ a very definite membrane is lifted off, which must be the original surface film of the animal for the cilia may be seen beating on it. The original surface of Paramoecium within the membrane lifted off (in $\mathrm{NaOH}$ ) is often perfectly clear and distinct and trichocysts may be seen beneath it. Lifting off of the whole ectoplasm plus pellicle by the accumulation of liquid beneath, occurs also in $\mathrm{NaOH}$. Where this does not take place we must regard the membrane formed as either the pellicle or a haptogen film on the surface of the clear drops. The fact that this film is impermeable for $\mathrm{NaOH}$ points to the former alternative. 
excluded dust and prevented evaporation. The water was redistilled in glass from $\mathrm{K}_{2} \mathrm{Mn}_{2} \mathrm{O}_{8}$ and $\mathrm{NaOH}$ and was non-toxic. The first third of the distillate was rejected.

Two different cultures of Paramoecia were used and they showed characteristic differences, both as regards resistance to the toxic effect of the alkali and rate of penetration of the alkali. Different species of Protozoa show likewise quite different degrees of resistance. An Oxytricha, Chilomonas and a Colpidiumintroduced along with Paramoecium into certain of the alkaline solutions appeared quite unaffected while the Paramoecia themselves were killed in a short time.

The individuals used in experiments, the results of which are given in table 6 , were large and the amines and ammonias penetrated much less readily than in the second culture. The comparative differences between the alkalies are constant however.

In every instance the last seven substances enter Paramoecium readily and change the red dye to yellow; the first seven only enter long after all motion has ceased, and the organism is very much swollen and dead. If it burst or is crushed so that the surface is ruptured the alkali enters at once and turns the neutral red to yellow. Or if the animal's surface is changed by $\mathrm{CHCl}_{3}$ water or chloretone the alkali is found to enter immediately.

A detailed comparison of the effects produced by $\mathrm{NH}_{4} \mathrm{OH}$ and $\mathrm{NaOH}$ on stained Paramoecium will serve to make clear the differences between the two groups of alkalies, as regards diffusibility through cell membranes. The second culture of smaller individuals was used in this comparison.

${ }_{1000} \mathrm{NH}_{4} \mathrm{OH}$-Paramoecia placed in this solution at first give the avoiding reaction. The movement is immediately slowed and the animals revolve slowly on their long axis first forward a short distance then backward. Change in shape begins immediately, the twist of the hind end becoming less marked. The change in color of neutral red also begins immediately; the red gradually fades and the animals are colorless in two to three minutes. Some individuals showed clear drops (vesicles) along the sides of the body in about four minutes. These individuals ceased movement in five minutes and disintegrated. The remainder (about half) simply swell often with protrusion of the 


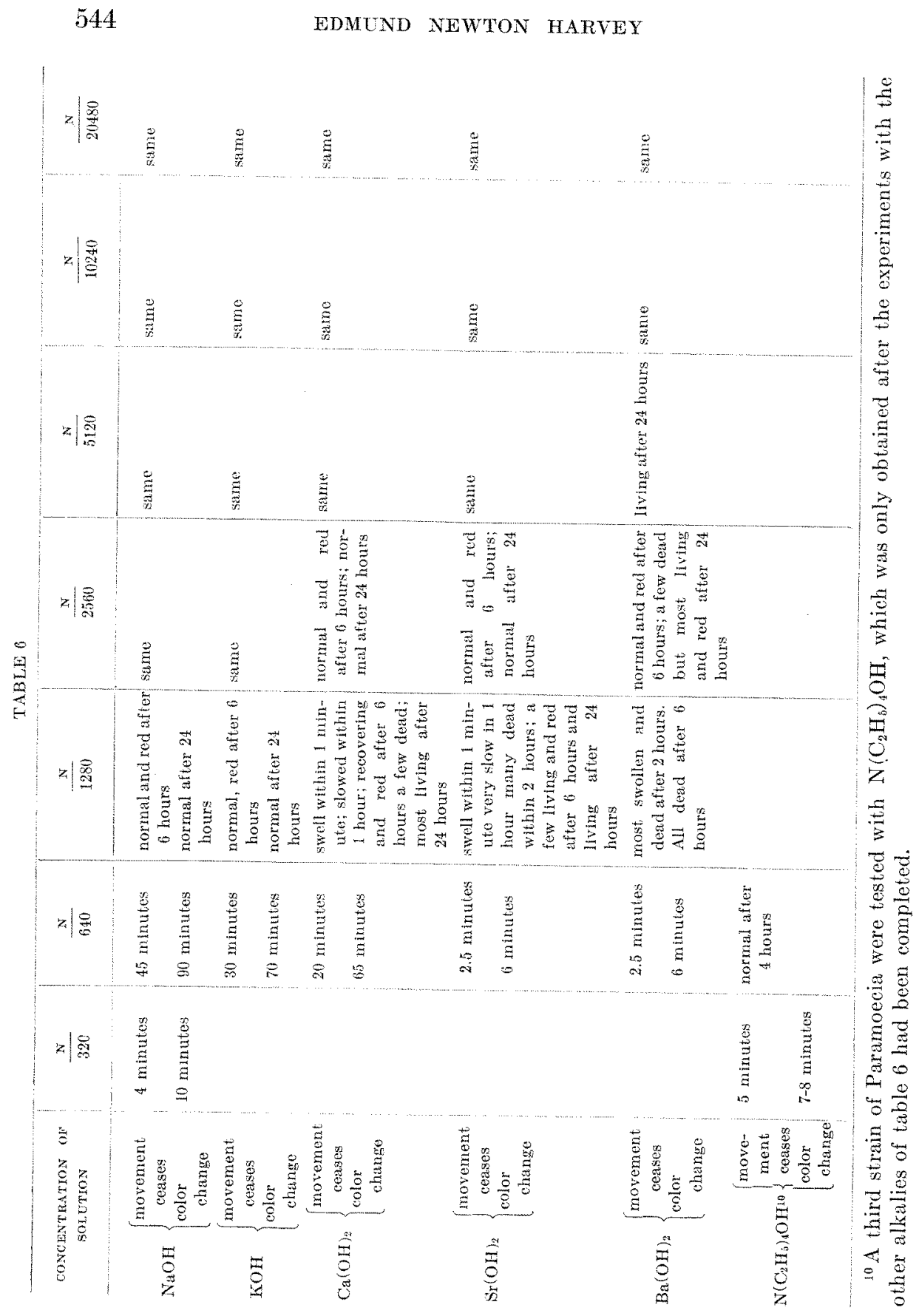




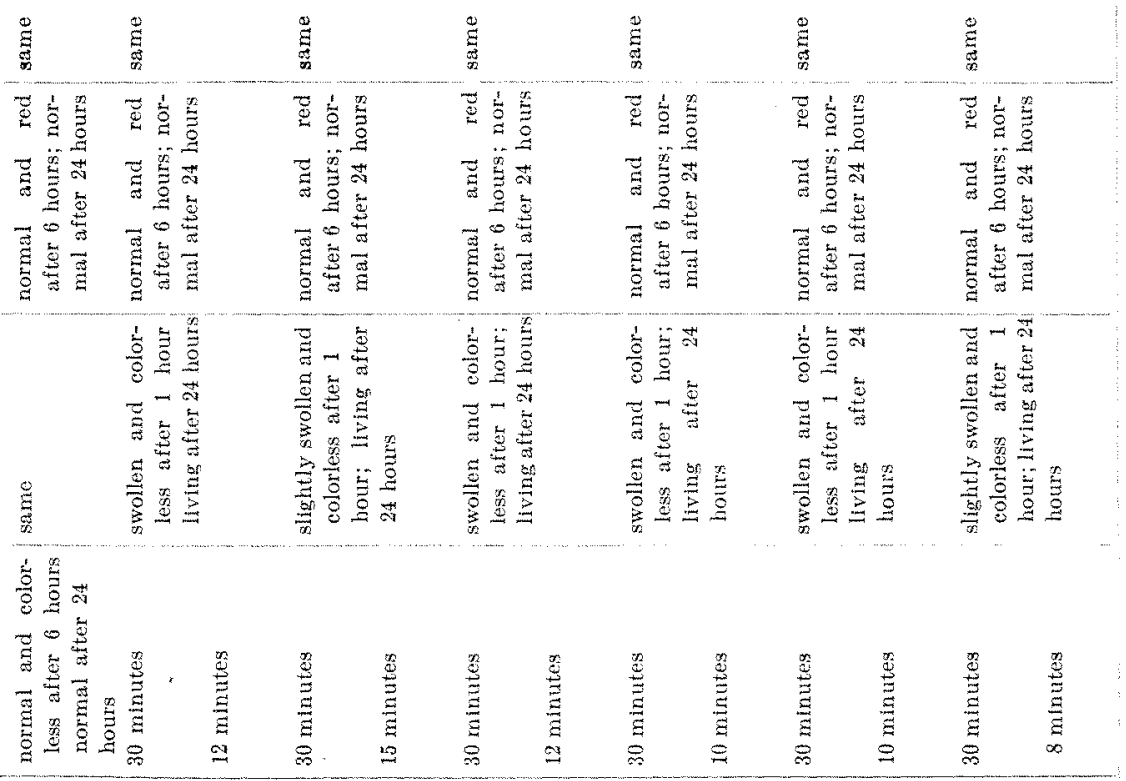

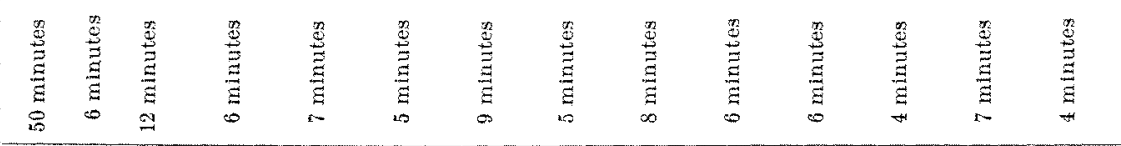

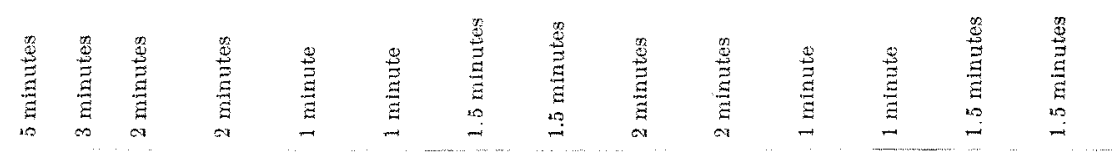

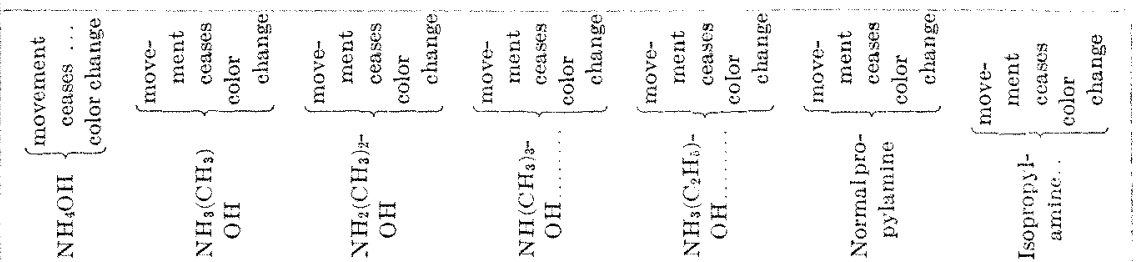


ectoplasm bearing cilia, but swim about normally although slowly for over fifteen minutes. A much more rapid rate of swimming is regained soon after the slowing, which takes place when first subjected to the action of the solution.

$\frac{\mathrm{N}}{500} \mathrm{NaOH}-$ Paramoecia placed in this solution swim rapidly forward but in less than one quarter minute they stop short and give the avoiding reaction. Many stop suddenly and swim rapidly backward. Change in shape begins immediately and in three minutes they are much shorter and broader and move slowly forward, circling about their long axis. In four minules clear drops (vesicles) and also clear protrusions appear on the surface. The protrusions may contain many red stained granules. After eight minutes some individuals have burst and the neutral red, which up to this time has been red, immediately turns yellow. Most of the Paramoecia burst before twelve minutes but a few are still moving very slowly and appear as red as when first placed in the solution.

Essentially, the series of changes undergone in the two solutions is the same. The $\mathrm{NH}_{4} \mathrm{OH}$ meets no resistance at the surface and the red color may be seen to change gradually to yellow, which diffuses out leaving the organisms colorless, from the moment they are placed in the solution. The change is complete before droplets appear at the surface or movement ceases. $\mathrm{NaOH}$ does not enter until after movement has ceased and the organism is enormously swollen and has lost all semblance to its original shape. Red granules may be present directly under the surface yet they remain red. Once the $\mathrm{NaOH}$ does begin to enter it does so rapidly and what is left of the Paramoecia becomes first yellow then colorless, in less than two minutes from the time the alkali begins to pass in.

We must draw the conclusion, that the $\mathrm{NaOH}$ produces the changes in behavior, the vesicle formation, the cessation of movement and the final death of the animal, all by an effect on its surface membrane. So long as $\mathrm{NaOH}$ alone was studied I could never be sure that a small amount of $\mathrm{NaOH}$, too small to affect the red stained granules, did not enter and was not responsible for the observed changes. But the comparison with $\mathrm{NH}_{4} \mathrm{OH}$ shows how low the $\mathrm{OH}$ ion concentration that is required to decompose the red granules really is provided the alkali may enter 
freely. Ammonia, likewise, must affect the membrane in time since it produces change in behavior, vesicle formation, cessation of movement and finally death, but the changes produced bear no relation to the time of entrance.

Even in very dilute solutions $\mathrm{NH}_{4} \mathrm{OH}$ and the amines are able to 'decolorize' stained Paramoecia but it takes a longer time. Yet in equivalent molecular concentrations of $\mathrm{KOH}, \mathrm{NaOH}$, etc., the animals sometimes retain their red color for 24 hours. Generally they are found to be colorless in that time. The decolorization is not due to the slow entrance of alkali because the same red individuals placed in distilled water are found to be colorless after 24 hours, although otherwise unchanged. A comparison after a shorter time, six hours, must be made. The results are given in table 6 .

$\mathrm{NH}_{4} \mathrm{OH}$ enters the cell readily and sets free a small amount of the neutral red base from its granule combination. The freed base diffuses out into the medium and more $\mathrm{NH}_{4} \mathrm{OH}$ enters. Thus the process is repeated until the organism is quite colorless. That the same decolorization does not take place in $\mathrm{KOH}$ must be due to the fact that the $\mathrm{KOH}$ does not enter freely.

In very weak concentrations $\left(\frac{N}{102 \overline{0}}\right) \mathrm{NH}_{4} \mathrm{OH}$ fails to affect the red color of stained Paramoecia at all. This concentration is presumably below the limit necessary to free the neutral red from its combination with the granules.

b. Marine eggs: In the following experiments the eggs of both Toxopneustes and Hipponoë were used. The sea water at Boca Grande, ${ }^{11}$ where the experiments were performed is markedly alkaline to neutral red and faintly so to phenolpthalein. If Toxopneustes eggs, unfertilized, are placed in $100 \mathrm{cc}$. sea water +1.2 cc. $\frac{\times}{10} \mathrm{NaOH}$ sufficient alkali does not enter them to turn the neutral red yellow for over three hours. If chloroform is added to the sea water, the eggs almost instantly turn yellow. Chloroform likewise causes the eggs to swell (cytolysis), an effect prevented in plant cells by the presence of a cellulose wall, and the penetration of the alkali might be connected with the swell-

11 About twelve miles west of Key West and sixty miles east of Tortugas. 
ing. The following experiment in which cane sugar is added to the sea water shows that in the presence of chloroform the alkali may enter the eggs before swelling of the egg has begun. Sugar prevents rapid pushing out of the artificial fertilization membrane which is relatively impermeable to it.

A. 10 cc. (50 cc. sea water +10 cc. $2 \mathrm{~m}$ cane sugar $)+0.15$ cc. $\frac{\mathrm{N}}{\mathrm{i} \sigma} \mathrm{NaOH}$ saturated with cholorform.

Neutral red stained eggs are turned yellow in 3-4 minutes. After about 5 minutes swelling is noticeable. If an acid is added the eggs are turned pink again.

B. Control (10 cc. ( 50 cc. sea water +10 cc. $2 \mathrm{~m}$ cane sugar) +0.15 ce. $\frac{\mathbb{N}}{10} \mathrm{NaOH}$.

Red stained eggs remain red for over three hours, in the meantime undergoing irregular division and fragmentation. Even very small fragmented spheres retain their red granules intact, providing their surface is likewise intact.

Just as in Paramoecium, observation of the manner in which the color change occurs points to the view that the alkali only enters after it has destroyed the surface. In immature Pentaceros eggs the red staining granules are present at the periphery separated from the alkaline solution only by the surface film of the egg. Yet they remain red for 15 minutes in $\frac{\mathrm{N}}{32 \pi} \mathrm{NaOH}$ in $0.6 \mathrm{n} \mathrm{NaCl}$. Once the $\mathrm{NaOH}$ begins to enter the color change is very rapid and the egg swells simultaneously.

The same is true of Toxomneustes where the red granules are uniformly distributed. There is never a gradual entrance of alkali from the moment the eggs are placed in the alkaline solution but after a certain interval the $\mathrm{NaOH}$ passes the surface and then it may be seen to move rapidly within the egg.

Toxopneustes eggs even undergo irreguiar division in hyperalkaline sea water $(100 \mathrm{cc}$. sea water $+1.3 \mathrm{cc} . \stackrel{\mathrm{N}}{0} \mathrm{NaOH})$ without the entrance of enough alkali to change the red to yellow. I have not experimented with $\mathrm{NH}_{4} \mathrm{OH}$ but it is probable, judging from my Paramoecium experiments, that this alkali would pass into the eggs freely and induce the color change before division, cytolysis, or any injury to the egg takes place. If such were the case it would show that the action of $\mathrm{NaOH}$ as a parthenogenetic 
agent must be on the egg suriace alone and not the catalytic acceleration of any reactions within the egg through an excess of $\mathrm{OH}$ ions.

A resistance to the entrance of $\mathrm{NaOH}$ is likewise shown by the eggs of Holothuria Floridana, Hipponoë esculenta, Pentaceros, reticulatus, and Asterias vulgaris.

A comparison of the entrance of alkali into fertilized and unfertilized eggs has shown that the fertilized eggs of Toxopneustes are much more readily entered by $\mathrm{NaOH}$ just after fertilization and again about the time of first cleavage. Only one experiment was performed toward the end of the breeding season and the eggs of the female used cleaved in the control in many instances somewhat irregularly. A stock solution of $\frac{\mathrm{N}}{32 \sigma} \mathrm{NaOH}$ in $0.5 \mathrm{~m}$ $\mathrm{NaCl}$ was made up. The unfertilized and fertilized eggs at intervals after fertilization were compared with each other as to entrance of $\mathrm{NaOH}$, in separate watch glasses over a white background. It is thus easy to see when all the eggs have been entered by the alkali, and their original red color changes to yellow. The following table shows the result.

\begin{tabular}{c|c|c} 
THME AFTER FRRTLLIZATION & $\begin{array}{c}\text { TIME TO TURN FERTILIZED } \\
\text { EGGS YELLOW }\end{array}$ & $\begin{array}{c}\text { TIME TO TURN UNFERTY- } \\
\text { LIZED EGGS XELLOW }\end{array}$ \\
\hline $\min$. & $\operatorname{min.}$ & $\min$ \\
2 & 13 & 19 \\
5 & 14 & 21 \\
10 & 19 & 19 \\
20 & 20 & 22 \\
30 & 21 & 21 \\
45 & 17 & 20 \\
55 & 21 & 21 \\
65 & 20 & 20 \\
\hline
\end{tabular}

The eggs begin to cleave about 45 minutes after fertilization. A somewhat similar result is obtained by comparing mature Asterias eggs fertilized and unfertilized, as well as eggs treated with acetic acid. The latter form artificial membranes. The results are shown in the following experiment. 


\begin{tabular}{|c|c|c|}
\hline & $\frac{N}{160}$ & $\begin{array}{l}\mathrm{N} \text { NaOH in } \\
0.6 \mathrm{~m} \mathrm{NaCl} .\end{array}$ \\
\hline Fertilized eggs ( 4 minutes after fertilization). & $\begin{array}{c}\min \\
5\end{array}$ & $\begin{array}{c}\min \\
15\end{array}$ \\
\hline Fertilized eggs ( 20 minutes after fertilization).. & 6 & 20 \\
\hline Unfertilized eggs (control)............. & 11 & 30 \\
\hline Unfertilized eggs ( 5 minutes after acetic treatment)... & 6 & 20 \\
\hline
\end{tabular}

Contrary to the results obtained in the Toxopneustes experiment it will be noted that the starfish eggs did not regain their original resistance to $\mathrm{NaOH}$ a short time after fertilization.

While it is of course true that in time $\mathrm{NaOH}$ may enter sea urchin eggs as well as Paramoecium or plant cells, and in this sense they are difficultly permeable, it seems becter, in considering the inorganic alkalies and $\mathrm{N}\left(\mathrm{C}_{2} \mathrm{H}_{5}\right)_{4} \mathrm{OH}$, to speak of a resistance of the cell against their entrance rather than a permeability of the cell for alkalies as I have done in a preliminary report ('10). The change undergone at the time of fertilization results in a surface less resistant to the penetration of alkali. At the same time the decrease in resistance for alkali is presumably connected with an increases in permeability for other substances notably the salts of sea water, as indicated by the experiments of MeClendon ('11) and Lyon ('10).

In working with Elodea (p. 539) I was able to show that small concentrations of chloroform which inhibited the protoplasmic rotation, but without any irreversible changes, increased the rate with which $\mathrm{NaOH}$ entered the cells. Exactly the same fact may be shown for the sea urchin's egg as the following experiment indicates. Unfertilized Hipponoë eggs stained in neutral red were placed in these solutions.

$A$. $\underset{\mathbb{N}}{\mathbb{N}} \mathrm{NaOH}, \frac{1}{4}$ saturated with chloroform, in $\frac{5}{8} \mathrm{~m} \mathrm{NaCl}$.

B. ${ }_{3}^{\frac{\pi}{2}} \mathrm{NaOH}$ in $\frac{5}{8} \mathrm{~m} \mathrm{NaCl}$.

C. $\frac{1}{4}$ saturated chloroform in $\frac{5}{8} \mathrm{~m} \mathrm{NaCl}$.

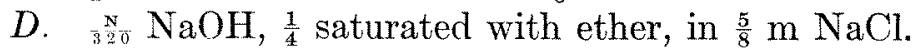

E. $\frac{1}{4}$ saturated solution of ether in $\frac{5}{8} \mathrm{~m} \mathrm{NaCl}$.

In solution $A$ the alkali has turned the eggs yellow in 10 minutes, in $\mathrm{D}$ in 6 minutes and in $\mathrm{B}$ in 20 minutes. Eggs in the chloroform 
control, C, were uncytolyzed in one hour and about one-half of them cytolyzed in the course of two hours. Eggs of the ether control, $\mathrm{E}$, were unaffected in 30 minutes and one-half of them cytolyzed in 45 minutes.

\section{DISCUSSION}

In an extensive paper, Barratt ('04) has studied the action of both acids and alkalies on Paramoecium; my results on alkalies are in fair quantitative agreement with his. Barratt came to the conclusion that neither the alkali nor acids produced their effect by a catalytic splitting of any substances in the organism but by a combination of the acid and alkali with the protoplasm. It was proved that the concentration of acids and alkali decreases in solutions in which a large number of Paramoecia had been placed. Three methods of determining this were used, viz.: (1) the use of an indicator, (2) measuring the electrical conductivity, (3) ('05) determining the E. M. F. by means of hydrogen electrodes. Only a relatively small amount of acid and alkali combines. One hundred parts of living Paramoecium take up 0.25 parts of HCL and 1.5 parts of $\mathrm{NaOH}$.

I fully agree with Barratt that the toxicity of the alkalies bears no relation to the $\mathrm{OH}$ ion concentration. The order of toxicity for Paramoecium is $\mathrm{N}\left(\mathrm{C}_{2} \mathrm{H}_{5}\right)_{4} \mathrm{OH}(?)<\mathrm{Na}$ or $\mathrm{K}$ or $\mathrm{Ca}<\mathrm{Sr}$ or $\mathrm{Ba}<\mathrm{NH}_{4}<$ amines. The degree of dissociation is $\mathrm{NH}_{4}<\mathrm{N}$ $\left(\mathrm{CH}_{3}\right)_{3} \mathrm{H}<$ primary and secondary amines $<\mathrm{N}\left(\mathrm{C}_{2} \mathrm{H}_{5}\right)_{4}<\mathrm{Ba}$, Sr, $\mathrm{Ca}, \mathrm{K}, \mathrm{Na}$.

Comparison of all the alkalies above mentioned in regard to toxicity is hardly legitimate since che two distinct classes, the strong and the weak, differ so in their power of penetrating the cell. It is to the rapid entrance of the weak alkalies, that their greater toxicity and general difference in physiological action is to be referred. ${ }^{12}$ But even among the strong alkalies, equally

12 Mathews (American Journal of Physiology, vol. 18, p. 58, 1907) states that the nucleolus of Asterias eggs immediately disappears from view in $\mathrm{NH}_{4} \mathrm{OH}$ and $\left(\mathrm{NH}_{4}\right)_{2} \mathrm{CO}_{3}$ but not in $\mathrm{NaOH}$ or $\mathrm{Na}_{2} \mathrm{CO}_{3}$. This is possibly due to solution in the entering $\mathrm{NH}_{4} \mathrm{OH}$. The NaOH cannot enter and no solution takes place. The carbonates are hydrolytically dissociated into $\mathrm{NH}_{4} \mathrm{OH}$ and $\mathrm{NaOH}$ respectively. 
dissociated in dilute solutions, there are characteristic specific differences, as a comparison of $\mathrm{Ba}$ and $\mathrm{Na}$ will indicate. These two substances differ markedly in toxicity even though they both fail to pass the cell surface.

On the other hand, Barratt's conclusion is not in accord with the observation of Paul and Kronig ('96) who found $\mathrm{Na}, \mathrm{Li}$, and $\mathrm{KOH}$ equally toxic to bacterial spores and $\mathrm{NH}_{4} \mathrm{OH}$ less so. Loeb ('97) also found that the increase in weight of muscle caused by $\mathrm{Li}, \mathrm{Na}, \mathrm{K}, \mathrm{Sr}$, and $\mathrm{Ba}$ hydroxides depends on the $\mathrm{OH}$ ion concentration.

As previously stated the power of penetration, in general, bears no relation to the toxicity except among the strong alkalies which fail to enter until the cell is fatally affected. Among the weak alkalies $\mathrm{NH}_{4} \mathrm{OH}$ enters most rapidly yet is less toxic, than methyl or dimethyl amine.

The most apparent relation is between the rate of entrance and the degree of dissociation. The weak alkalies enter rapidly, the strong very slowly. $\mathrm{N}\left(\mathrm{C}_{2} \mathrm{H}_{5}\right)_{4} \mathrm{OH}$ is an excellent confirmation of the rule. A priori it was to be expected that the tetra-alkyl substitution product of $\mathrm{NH}_{4} \mathrm{OH}$ would behave just as its primary, secondary, and tertiary derivatives. Tetraethylammonium hydroxide should enter cells rapidly yet such is not the case. The substitution of four $\mathrm{C}_{2} \mathrm{H}_{5}$ groups for four $\mathrm{H}$ atoms gives a substance whose degree of dissociation may be compared with the strongest inorganic bases, $\mathrm{Na}$ or $\mathrm{Ba}$. Correspondingly its power of penetrating cells is likewise limited and comparable with that of $\mathrm{Na}$ or $\mathrm{Ba}$.

The general relation between the dissociation or chemical reactivity of the alkalies and their power of penetrating cells suggests that, while we appear to be studying cell permeability, we are in reality confronted with phenomena of reaction velocity, depending on the strength of the base. $\mathrm{NH}_{4} \mathrm{OH}$ may appear to penetrate readily, because, being a weak base, it combines with the cell proteids less rapidly and so may affect the neutral red. $\mathrm{NaOH}$ appears to meet a resistance because it combines readily with the cell proteids as it enters and cannot affect the neutral red. But in both cases the proteids must be acted upon before the 
indicator is affected. Were the relation of $\mathrm{Na}$ and $\mathrm{NH}_{4}$ reversed, some probability for such an explanation might be found. The evidence (p. 528) that combined $\mathrm{NH}_{4} \mathrm{OH}$ or $\mathrm{NaOH}$ albumen does not affect neutral red even in solution, that chloroform has no influence on the combining power of albumen for alkali, whereas cells killed by chloroform become as readily permeable for $\mathrm{NaOH}$ as for $\mathrm{NH}_{4} \mathrm{OH}$ is strong proof that permeability and not reaction velocity is in reality the phenomenon studied. Robertson's ('10) experiments on the solution of casein in alkalies indicate that equal concentrations of $\mathrm{Na}, \mathrm{K}, \mathrm{Li}$, and $\mathrm{NH}_{4}$ dissolve equally well. Even though the velocity of solution is mainly due to the rate of wetting of the casein particles by the alkali, the analogy is all the closer to diffusion into a cell and any marked differences in $\mathrm{NH}_{4} \mathrm{OH}$ and $\mathrm{NaOH}$ should appear.

Lastly, it must be pointed out that the rate of penetration is not exactly inversely proportional to the degree of dissociation. Among the weak alkalies trimethyl amine is much less dissociated than methyl amine yet enters Elodea less rapidly.

Overton's study of the penetration of the weak organic bases into Spirogyra cells as indicated by precipitation of a tannate has brought out the relation which exists between lipoid solubility and permeability. According to Overton, ammonia and the amines with the exception of the quaternary ammonium bases are lipoid soluble. The two classes into which we may divide the alkalies in respect to their power of penetrating living cells are just the classes into which we may divide the alkalies in correspondence to Overton's hypo hesis. Traube has shown however that the lipoid solubility of a substance is also connected with a lowering of the surface tension of water by that substance. It is to this property that he refers the ready penetration of lipoid soluble substances, in accordance with his theory of osmosis. It is quite probable that the relations shown by the alkalies may be brought into line with Traube's theory but I have no data on the subject and cannot at present discuss the question.

I also agree with Barratt that $\mathrm{NaOH}$ combines with certain constituents of Paramoecium but would limit the combination 
to the surface layer only. This would explain the relatively small amount of alkali which Barratt found to be taken up.

The change thus brought about in the cell surface alters its properties in three conceivable directions,--surface tension, electrical polarization and permeability. The alteration in the latter property is in the direction of an increase in permeability, since finally the surface becomes so altered as to allow the inorganic alkali itself to pass.

In Paramoecium, cytolysis, in Elodea, rotation, and in the sea urchin egg, irregular fragmentation and division result before any appreciable amount of $\mathrm{NaOH}$ has entered. We must consider then, that all these changes are essentially an expression of some profound alteration in the cell surface, involving one or all of the properties mentioned above.

In recent years more and more stress has been laid on the importance of a surface layer differing markedly from the interior of the cell and the role played by surface energy in cell dynamics. It seems that we cannot attribute too much functional value to this barrier or passageway between cell and environment, the 'Umwelt und Innenwelt.' Life has been defined as "the continuous adjustment of internal relations to external relations." Should we not, therefore, look to the boundary between the two 'worlds' for an explanation of many of the phenomena exhibiting such unusual characteristics as to receive the special designation - vital?

\section{SUMMARY OF RESULTS}

1. The basic dyes fail to enter cells in the acid condition, i.e., as the dye salt. Certain acid dyes do enter in the acid condition but not in neutral or alkaline solution. The latter combine with the nucleus and protoplasm leading to death of the cell; the former (in the concentrations used) with non-essential elements. In animal cells, these elements are granules which may be distinguished by their specific gravity. As a general rule they are the heaviest substances present, as determined by the centrifuge. 
2. Using neutral red as an indicator within the cell it was found that both animal and plant cells behave similarly with respect to the penetration of organic and inorganic hydroxides. Two classes may be recognized, the strong alkalies $\left(\mathrm{N}\left(\mathrm{C}_{2} \mathrm{H}_{5}\right)_{4}{ }^{-}\right.$ $\mathrm{OH}, \mathrm{Na}, \mathrm{K}, \mathrm{Ca}, \mathrm{Ba}$, and $\mathrm{Sr}$ hydroxides) and the weak $\left(\mathrm{NH}_{4} \mathrm{OH}\right.$ and the amines). The former enter with difficulty and only after destroying the normal properties of the surface; the latter, readily, and independently of such surface action. Both classes penetrate dead cells rapidly. Difference in physiological action is to be referred to their respective powers of penetration.

The inorganic alkalies produce very marked functional changes without appreciably penetrating the cell. Such action must be attributed to an alteration of the surface layer. Functional changes cannot therefore be used as a criterion of permeability.

Decrease in the resistance of the cell surface may also be brought about by quantities of ether, alcohol, chloroform, and various salts too small to produce any irreversibie effects. Normal variations in resistance also occur amorg cells apparently in the same condition of functional activity or between cells known to be in different conditions of activity (the unfertilized as compared with the developing egg).

Considering all the alkalies studied, there is no relation between toxicity and penetrating power. This is likewise true for the class of weak alkalies. Those strong alkalies are most toxic which most readily dest:oy the resistance of the plasma membrane. Hence, using permeability in the broad sense, the most toxic of the strong alkalies penetrate the cells most rapidly. The two classes support Overton's hypothesis in their lipoid solubility and penetrability reations and probably also that of J. Traube.

\section{BIBLIOGRAPHY}

Barratt, J. O. W. 1964 Zeitschrift für allegemeine Physiologie, Bd. 4, p. 438. 1905 Id. E.d. 5, p. 10.

DeVries, H. 1871 Archiv. neerlandaises des sciences exactes et naturelles. T. 6 , p. 124 .

1877 Die mechanischen Ursachen der Zellstreckung, Leipzig. 1884 Jahrbücher fur wissenschaftliche Botanik, Bd. 14, p. 427.

1885 Id. 16. p. 465. 
Budgett, S. P. 1898 American Journal of Physiology, vol. 1, p. 210.

Harvex, E. N. 1910 Science, N. S., vol. 32, p. 565.

Hokber, R. 1906 Physicalische Chemie der Zelle und der Gewebe. Leipzig. 1909 Biochemicshe Zeitschrift, Bd. 20. p. 56.

HörmanN, J. 1898 Protoplasmaströmung bei den Characeen. Jena.

LiLLIe, R. S. 1911 American Journal of Physiology, vol. 27 p. 289.

LOEB, J. 1897 Pflüger's Archiv. Bd. 69, p. 1.

Lyon, E. P. 1910 Seience, N. S. Bd. 32, p. 249.

Matuews, A. P. 1898 American Journal of Physiology, vol. 1, p. 445.

Mathews, A. P. and Longfellow, E. 1910 Journ. of Pharm. and Exp. Ther. vol. 2, p. 201.

MoClendon, J. F. 1910 Archiv für Zellforschung, Bd. 5, p. 387. 1911 Journal of Physiology, vol. 27, p. 241.

Moore, B. and Rosf, H. E. 1907 Biochemical Journal, vol. 3, p. 55.

NÄGELI, C. 1855 Pflanzenphysiologische Untersuchungen, Bd. i, p. 21.

Nathanson, A. 1902 Jahrbücher für wissenschaftliche Botanik, Bd. 38, p. 241. 1904 a Id. 39 . p. 607. $1904 \mathrm{~b}$ Id. 40 , p. 403 .

Osterhovt, W. T. V. 1908 On plasmolysis. Botanical Gazette, vol. 46, p. 53.

Oventon, E. 1895 Vierteljahrsschrift der Naturforschenden Gesellschaft in Zurich. Bd. 40, p. 159.

1897 Zeitschrift fur physickalische Chemie, Bd. 22, p. 189.

1899 Virteljahr. der. Naturfor. Gesell. in Zurich, Bd. 44, p. 110.

1900 Jahrbücher für wissenschaftliche Botanik, Bd. 34, p. 669

Pavl and KröNıg. 1896 Zeitschrif́t für physikalische Chemie, Bd. 21, p. 414

Pfeffer, W. 1877 Osmotische Untersuchungen. Leipzig.

1886 Untersuchungen aus dem botanischen Institut zu Tubingen, Bd.2. 1890 Plasmahaut und Vacuolen. Abhandlungen der math-phys. Kl. Sachs. Gesellschaft, Bd. 16, p. $18 \%$.

Quincke, G. 1888 Wiedemann's Annalen, Noue Folge, Bd. 35.

Robertson, T. B. 1908 Journal of Biological Chemistry, vol. 4, p. 1. 1910 Journal of Physical Chemistry vol. 14, p. 377.

RUHLAND, W. 1908a Jahrb. f. wissen. Bot. Bd. 16, p. 1. 1908b Berichte der deutschen Botanischen Gesellschaft, Bd. 26, p. 772.

Traube, J. 1904a Pflüger's Archiv. Bd. 105, p. 541.

$1904 \mathrm{~b}$ Id. Bd. 105, 559.

1908 Id. Bd, 123, p. 419.

1909 Biochemische Zeitschrift, Bd. 16, p. 182.

1910 Pflüger's Archiv. Bd. 132, p. 511.

Traube, M. 1867 Reichert's und Dubois Reymond's Archiv.

Wulzen. R. 1909 Quarterly Journal of Experimiental Physiology, vol. 2, p. 293. 